\title{
COMMENTS ON CERTAIN
}

\section{IROQUOIS MASKS}

BY

JOSEPH KEPPLER

(Gyantwaka) 



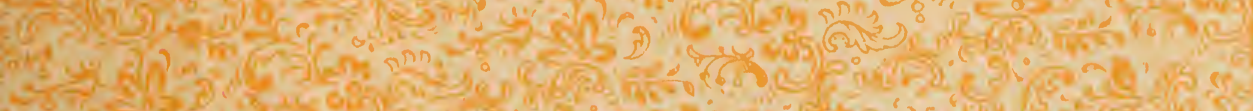

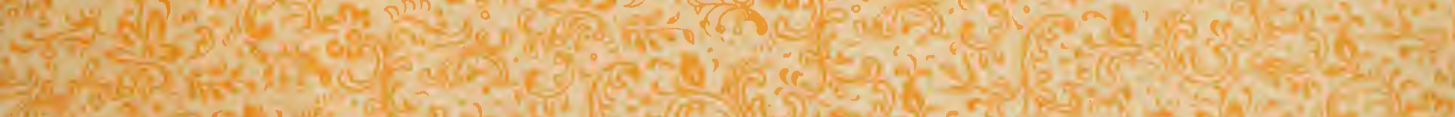
W axts

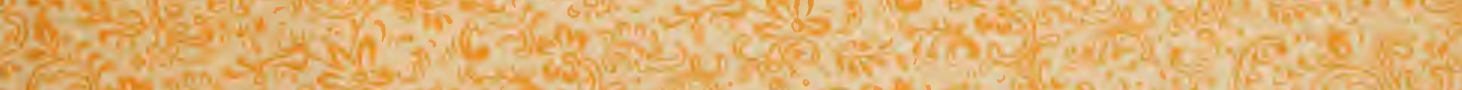

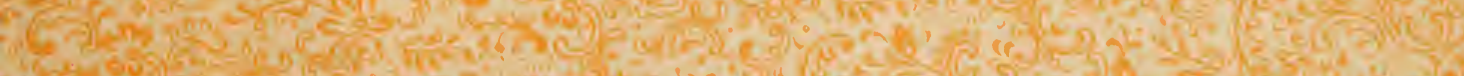

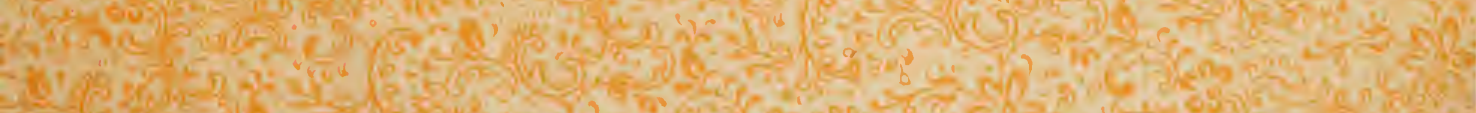
(5)

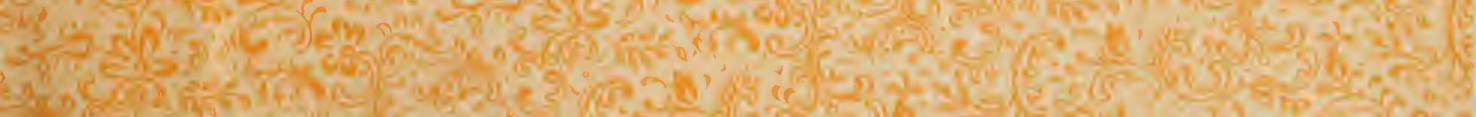

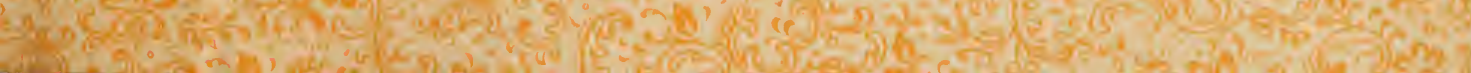





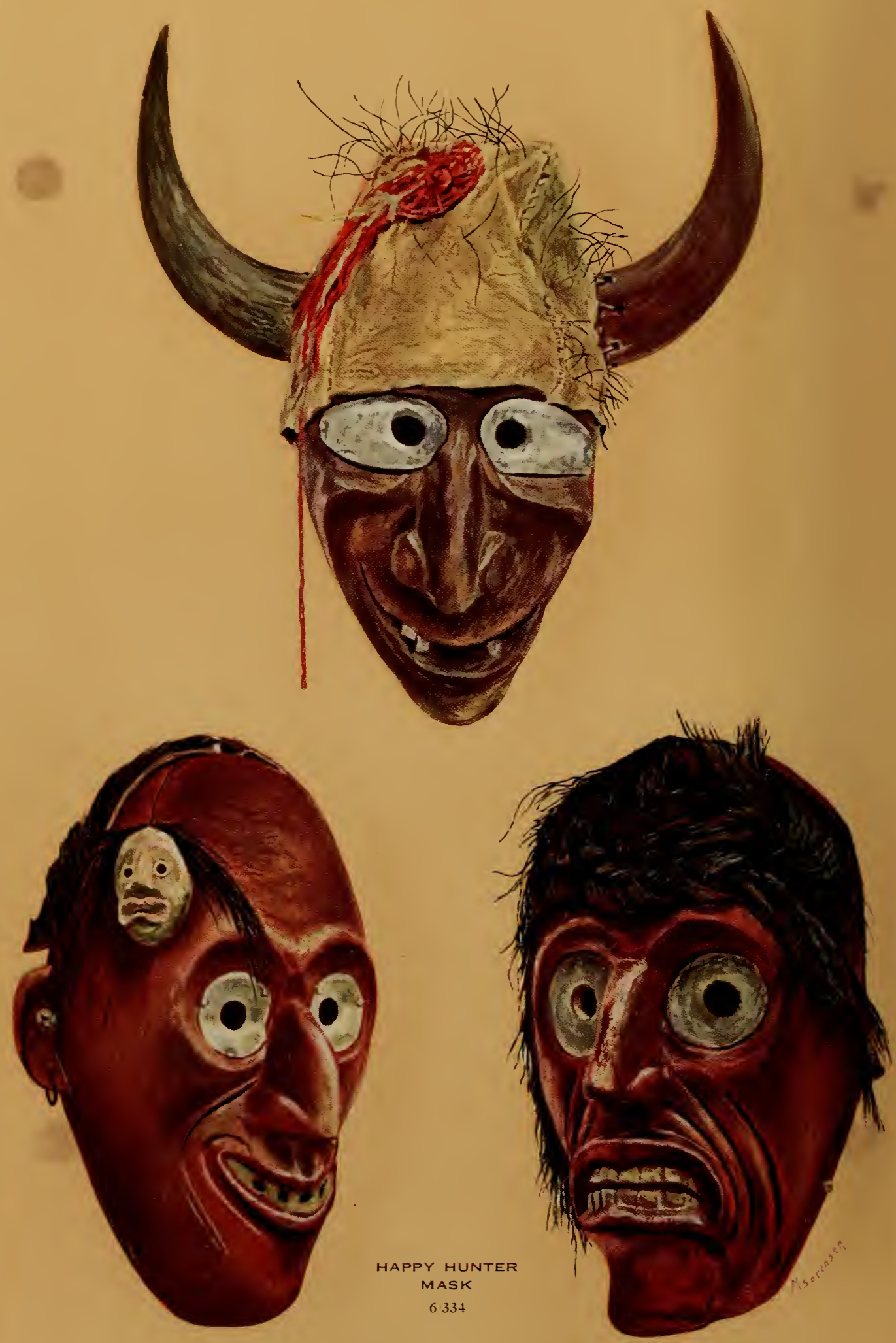

FEMALE MASK 


\title{
FRONTISPIECE
}

\author{
Happy Hunter Mask \\ $6 / 334$ \\ Seneca, Cattaraugus Reservation, New York. \\ Height (to top of hat) : $123 / 4$ in.
}

Female Mask

$2 / 9605$

SeneCA, Cattaraugus Reservation, New York.

Height: 11 in.
Avenging Scalp Mask

2/9599

Seneca, Cattaraugus Reservation, New York.

Height: $91 \frac{1}{2}$ in. 

CONTRIBUTIONS FROM THE

MUSEUM OF THE AMERICAN INDIAN

HEYE FOUNDATION

Vol. XII, No. 4

\section{COMMENTS ON CERTAIN \\ IROQUOIS MASKS}

BY

JOSEPH KEPPLER

(Gyantwaka)

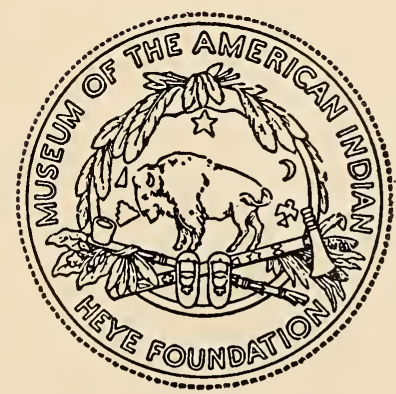

NEW YORK

MUSEUM OF THE AMERICAN INDIAN

HEYE FOUNDATION

1941 



\section{CONTENTS}

PAGE

Animal Masks . . . . . . . . . . . . . . . . . . 36

Avenging Scalp Mask .................. 35

Bird Masks ...................... 36

Clan Mask .......................... 35

Completing Mask ................. 36

Cornhusk Mask . . . . . . . . . . . . . . . . 37

Counselor Mask ....................... 31

Dancing Beggar Mask .................. 32

Doctor Mask ........................ 25

Female Mask .................... 30

Happy Hunter Mask .................... 34

Harvest Mask ...................... 32

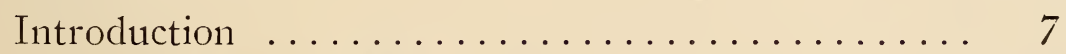

Laughing Dancer Mask ... . . . . . . . . . . . 34

Legends and Masks .................... 15

Live Mask ... . . . . . . . . . . . . . . . . . . . 23

Maternity Mask ....................... 29

Medicine Mask ...................... 25

Preface ......................... 9

Requiem ............................ 11

Scalp Mask ...................... 35

Societies .......................... 21

Some Thoughts ...................... 12

Treatment of Masks .................. 38

Wind Mask ...................... 34 



\section{LIST OF ILLUSTRATIONS}

Happy Hunter; Female; Avenging Scalp Masks

(in color) ................... Frontispiece

Crooked-face Masks ................. PL. II

Live Mask . . . . . . . . . . . . . . . . . . . . PL. III

Doctor or Medicine Masks .............. PL. IV

Maternity Masks ..................... PL. V

Female Masks ...................... PL. VI

Completing; Counselor Masks ............ PL. VII

Dancing Beggar Masks ............... PL. VIII

Bird; Harvest Masks . . . . . . . . . . . . . . PL. IX

Wind; Scalp Masks .................. PL. X

Clan Mask ....................... PL. XI

Doorkeeper Masks .................. PL. XII

Miniature; Cornhusk Masks ............ PL. XIII 



\section{INTRODUCTION}

Joseph Keppler, the author of the accompanying paper and the Vice-President of this Museum, has shown a lifelong interest in the American Indian, particularly the tribes of the Iroquois. This was occasioned by his friendship with the great student and benefactress of the Iroquois, Mrs. Harriet Maxwell Converse, whose Indian name, Yaiewanoh, signified She-who-watches-for-or-overus. Through her constant guidance his interest in those people increased.

Mr. Keppler was adopted by the Senecas about 1898 and was then formally inducted into the Wolf Clan of that tribe. Upon his elevation to a distinguished Pine Tree chieftainship, he "shed" the first name given to him, and the Clan elders elected him to the name and "horns" of Gyantraka, Cornplanter. This action was confirmed by the Seneca chiefs and ratified by the chiefs of the Onondaga.

On the death of Mrs. Converse, her "horns " of office were ceremonially conferred upon him, the wampum being lifted from her bier, and placed in his keeping.

Through business connections and his many friends Mr. Keppler always wielded what influence he could muster to encourage beneficial, and to defeat legislation adverse to his tribe's interest, and has given every effort to better their condition in all ways. No other white man knows the innermost lore of these people as he does, and that he has been finally persuaded to publish a small part of his knowledge of the beliefs of the great Iroquois people, is a cause of congratulation to students of the American Indian.

George G. Heite

New York DIRECTOR

February 1941 
Lo, the poor Indian! whose untutor'd mind Sees God in clouds, or hears him in the reind; His soul, proud Science never taught to stray Far as the solar walk, or milky way;

Yet simple Nature to his hope has giv'n, Behind the cloud-topt hill, an humbler heav'n; Some safer world in depth of woods embrac'd, Some happier island in the rwat'ry zwaste,

Where slaves once more their native land behold, No fiends torment, no Christians thirst for gold. To Be, contents his natural desire,

He asks no Angel's roing, no Seraph's fire; But thinks, admitted to that equal sky, His faithful dog shall bear him company.

Pope 


\section{PREFACE}

H AVING noted, in my time, the spread of so much misinformation and the existence of so many fallacious beliefs concerning the Indian, and knowing that much that has been told or written of him comes on one hand from the minds and pens of pioneer landgrabbers, lawless borderers or embarrassed army commanders, and, on the other, from blind sentimentalists, bigots and hypocrites, who, if not actual enemies of the Indian, did not try to understand him, I feel motivated to record a little known phase of Indian character expressed through a part of his ceremonial life. I still would hesitate to expose to the ken of many even this small part of his innermost feelings and the beauties of his ancient philosophy except in an endeavor to show his mental concepts and capacities to be developed far beyond the crudities and limitations of his material culture.

For three centuries, the number running into thousands, book after book has been written in which the motives and actions of the Indian have been interpreted through the inductive logic of the white man and judged by the dicta and sophistries of European civilizations. Many of the authors of these works suffer the same frustrations as do, for instance, most writers of animal stories who strive to express human intelligence and human reasoning in the reactions of natures that seek nothing in life save sustenance, safety and procreation. Let it not be inferred from this parallel that the Indian was more beast than human; but ever in close contact and communion with the expressions of Nature, strengthened by her stately passiveness, inspired by her active transformations, he was filled with a charity and compassion and possessed a high quality of spirituality not alone uncommon to the so-called civilized, but even less understood by them. 
Whether or not understood, these qualities of Indian character were consistently, many times purposely, overlooked by those who for selfish reasons painted word pictures in which his weaknesses were exaggerated, his lack of lettered education condescendingly ridiculed, and his ferocity luridly emphasized. In stressing his savagery, propagandists ignored the continued provocations offered by white settlers and their governments. Injustices, intrusions, solemn treaties ignored or broken-all fanned the flame of resentment to fever heat in the breasts of these emperors of hill and forest; and they struck back at the usurper and defiler in defense of their honor, their loved ones, and the land and graves of their forefathers.

In most of the recorded tales of those bitter days, Indian victories were always massacres, their stratagems, fiendish treacheries-quite in contrast to the actions of the white man, whose treachery was ever a high expression of strategy, whose senseless mass murders of Indian women and children were lauded as glorious feats of arms.

The crimes and atrocities of yesterday-proud products of civilization! Or are they only of yesterday? The blind, stupid struggle for autocratic power, the insatiate lust for gold-unholy appetites, sharpened, alas, too often by greedy theological princes whose temple altars are supposed to be mortised with temperance, tolerance and humility.

This monograph on the Falsefaces of my people, the Iroquois, makes no pretension to be a cold, objective, ethnographic study of their ceremonies. It strives, rather, to tell at least a portion of the legends and ministrations of the masks and the interpretation of these stories by the respected Old Ones of the Nation.

J. K. 


\section{REQUIEM}

7 HE glory of the Iroquois dims as their sun sinks slowly behind the western hills. No longer their

1 war-cry strikes terror; no longer their castles shelter the units of a great and robust nation; no longer their chiefs lead to glorious victories. Union and power gone, darkness closes about them.

The Great Tree, The Great Binding Law, Ne gayäneshägowa, it of wide-spreading roots and branches, of ever growing blossoms, of ever ripening fruit, planted in the old centuries and nurtured through the generations to protect the Nations and shower their peoples with peace and plenty, fell, withered of branch and rotted to the core by the foul winds of alien political systems.

Ongave onweh, the Iroquois reverently call their sires and proudly designate themselves. Ongre onceh, the Real Men. Among the colonists who witnessed their valor and who likened them to the Romans of old, some marvelled at the eloquence of their orators and many recognized their fervent love of home and freedom. Nevertheless, the ruthless impact of European civilization shattered the ethos of these people, seared the very soul of the ancient League, the Hodimosamee, and doomed it to decay and death.

Perhaps no ideology based on the lofty principles of the League could hope to survive the rapacious greed for land and still more land, so foreign to Indian philosophy. The sagacious and frank statesmanship that conceived, perfected and executed the laws of the League-a model largely copied in the construction of the Constitution of our own democracy - was no match for the lying intrigues 
and faithless promises of the white man from across the seas.

Though the League is now only a memory, scattered but faithful descendants. whose indoctrinated ideas of beharior and worship-although somewhat ravelled and lapsed by the passage and ricissitudes of time-cling to the practices and teachings of the revered ancestors. carry on. In mumbled ritual, in interpretations of ancient rites and ceremonies is found, vaguely recognizable, the cherished folk-lore of a glorious past.

But few addresses, chants or rituals have ever been interpreted correctly and adequately. The translators. in a majority of cases. apparently lacked the capacity to understand the workings of the Indian's mind or to plumb the depths of his feelings. and because of that and an inability to find equivalent words in a foreign language properly to express an eloquent innagery that was sustained through a truly remarkable continuity of thought. few indeed are the competent or comprehensive recordings of Indian speeches and ceremonies.

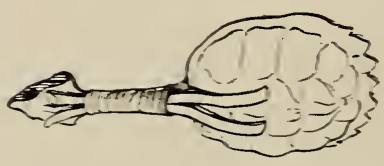

\section{SOME THOL'GHTS}

Who more than the Indian has indulged in such prolonged feats of meditation or has more sincerely sought spiritual communion with the unseen forces of the Great Mrstery? Who more than he has sensed the infinite as keenly: who has adored more deroutly: lived more fully: died more complacently and resignedly: His philosophy originated from no printed text. Nature, who offered 
fully of her boundless beauties yet who disciplined him through the operation of her inexorable laws, was at once mother and teacher; and from her alone came his understanding of the universe and the application of its systematic orders to his own existence.

The acceptance of an inevitable destiny of perpetual change, led to an understanding of the oneness of all created things and to a profound belief that everything, animate or inanimate, seen or unseen, possessed an entity, a soul-spirit, which survived all metamorphoses.

Man was looked upon as being the materialized form of the feelings, the thoughts and aims of his celestial prototypes whose qualities he possessed; and the creatures of air, water and land indicated and expressed the prevailing spiritual impulses of the human individual.

Man was visualized by Hodiänokdoon Hediohe, the Great Maker of All, whose personality could not be comprehended nor mentally conceived by humans and whose manifestations of infinite power extended through all the forces of Nature. When first created on the earth, man still retained some of the virtues and perfections of the Skyworld, despite the beginning of mental differences and the diversification of languages; and, although he was given the power of life and death over all other living things, he was granted no such control over his own.

The omnipotent Hodiänokdoon Hediohe, or Sogrwayadisso $^{n}$, as he was sometimes known, was never the object of individual supplication for help. Others were begged; he alone was thanked for all the manifestations of his loving protection. And no old-time Iroquois engaged upon an undertaking, no matter how trivial, without the accompaniment of some whispered or heart-thought prayer, nor did he fail to breathe his niavel of thankfulness when the object had been attained. 
The materialization of life in this world was executed and governed by the Twins. Hanigoivu, he of good, and Hanigon etg $\ddot{a}^{n}$. he of evil. The perfection in which man had been created was lost through his own wrong-doing. and because of the many self-induced weaknesses he suffered, man became vulnerable not alone to the domination of Segocicatha, the Tormentor, but to the stronger influences of those who might wish to do him harm. It was to the appeasement of such malignant forces-based on the same elements of fear that abound in all creeds-that the Indian directed thought and sacrifice to help ward off the lessening or complete loss of his personal orenda.

Orenda was a magic or psychic power individually inherent to all objects of his environment, both animate and inanimate. which might be strengthened by supplication and lessened or lost by failure properly to propitiate those forces which were considered to possess sufficient power to do him injury. Men who were adjudged to have led exemplary lives possessed a powerful orenda not enjoyed by the more dissolute, and they, therefore, were endowed with dependable powers. not alone of foresight and judgment, but of actual accomplishment.

It was the dominance of his orenda over that of an adversary, whether in life-or-death struggle or friendly footrace. that decided the issue, not the prowess of the contestant. Though given to public boastfulness over personal exploits, when the Indian was alone he gave calm and reverent thanks to his orenda which had overcome. through him, the weaker power of his antagonist. Medicine did not cure. nor did art or skill decide an issue: all success depended upon the power of this life-force to orercome those of others working against it.

Nor was the orenda considered to govern only contests of shill or valor. It acted prominently as a moral force 
and deterred those on warlike missions from the commission of sex atrocities. Although women of enemy nations might be captured, scalped or slain, they were never raped. Such an act would result in an impairment, possibly a complete loss, of the orenda of the culprit, a loss that would cause the entire expedition to fail and other great misfortunes to fall upon him and his comrades.

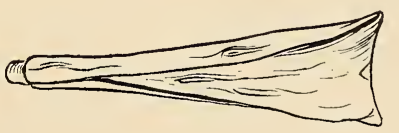

\section{LEGENDS AND MASKS}

Among all of the ancient beliefs still alive in the hearts of the Iroquois there is, to one who knows, none that typifies more clearly their native philosophy and their veneration and adherence to the tenets of their ancestors than the ritual use and ceremonial of the mask or falseface, gagolisa.

There exist many legends concerning the origin of the falseface, the dissemination of its use among the people, and the rites associated with it. All of the variations seem to agree in substance that Hodiänokdoon Hediohe, the Great Maker of All, while surveying the Earth-world, encountered in his travels a being named Shagodjioren gor'a. The latter, having lived among the Great Maker's creations without companions and without opposition to his assumptions of authority, in the course of time became imbued with the conceit that it was he who had caused all the forms of nature to have come into being, and boasted with great arrogance that not only was he the ruler, but, indeed, the creator, of all the earth-wonders about him. 
Thus. Shagodjion'en' goi'a viewed the strange newcomer with malerolent suspicion. particularly so when the Great Maker of All questioned him as to his activities and aims. A protracted argument ensued ending in a challenge to a contest to establish which of the two possessed the more dominant inherent powers. Tarious feats of mental and physical prowess were engaged in with almost equal ability until Shagodjioi'e' goi'a suffered chagrin and humiliation at not being able to more a mountain.

As Shagodjiorien gori'a stood dejected, the Great Maker of All with a ware of his hand caused a mountain to move directly back of his boastful adversary whom he then commanded to turn and look behind him. Angrily doing so, not knowing the power and intent of this stranger, Shagodjiou'e" gow'a struck his face violently against a rock ledge, the force of the impact breaking his nose, distorting his mouth and causing his tongue to protrude from between his teeth. The Great Maker of All, thus revealing himself and his supreme power, ordained that forever after Shagodjiowi gorid $^{n}$ suffer this distorted face as a constant reminder of his lack of belief in the omnipotence of the Creator: and as a specific punishment for his boastiulness and self-importance. his speech was thereafter limited to the utterance of a timid "hooo hooo hooo."

Hodiänokdoo" Hediohe spared the braggart's life only on the pronise that he would always work among the manbeings-to-be, imparting his knowledge to them as a protection against the enemies to health and happiness and as a means through which all pernicious influences and diseases might be driven from among them.

Thus did Shagodjiozien gori'a come to be known by men as " the Helper," with the renerable title of " Our Grandfather," and it was he who instructed man in the carving of falsefaces reminiscent of his own features, in the cere- 
monies to be employed in their ministrations, and in the proper forms by which emblematic portrayals or representations of spiritual powers assigned to combat and overcome all malignant influences were to be expressed.

As to the manner in which Shagodjiowe gowa fulfilled his mission, the second tradition tells of a weary hunter who heard a strange noise while roaming through a forest. Climbing in the direction of the sounds, he gradually ascended a high mountain and located a combined moaning and song emanating from a cave near the summit. Groping his way through the darkness of the cavern, he was suddenly confronted by an immense giant-monster creature with a hideously distorted face, who proceeded to question the hunter as to the reasons for his fatigue and to explain to him that his weakness and vulnerability to disease were due to eril influences that man himself permitted to enter and control him.

Shagodjiowe" gow'a then fashioned a huge falseface in his own likeness from the timber of a living tree, and instructed the man in the use and proper ritual of the mask as an aid in overcoming eril influences and human frailties. The monster then gave explicit instructions as to how the spirit of the mask was to be fed and how its material form was to be purified, and commissioned the hunter to spread the information among the earth-people.

Thus came the gagolısa to be given to all the people according to their totemic divisions. At first they were clan property, later on societies acquired them, and, more recently, falsefaces have come to be owned personally by individuals.

Masks either expressed the spirit or life of Shagodjiowe $^{n}$ gowa or assumed the duty of the mystic power of such exhorted impersonation conveyed to them, although 
not all were to be regarded as literal representations. They were but guides to an association of ideas that germinated from grare contemplation of the spirit of the falseface. The imagery thus eroked deepened the thought and added warmth to feelings induced by the suggestion of the gagohsa. It was the inspiration of the mask that was important, and often a crude or poor portrayal of feature led to most beautiful sentiments and thoughts.

At first, I beliere, all masks bore the features of the Shagodjioriengoi'a depicted as faithfully as the hunter could remember or describe them (pl. II). In the course of time slight differences erolved from the original concept, rariations which, though erer reminding of the Teacher's sufferings and disfigurement, emphasized certain characteristics proven by experience to be efficacious and omitted others that seemed useless. But the impersonator wearing the falseface always represented Shago-

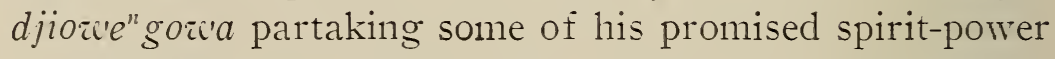
in officiating to "help" and inroking his intercession through the incense of the burning sacred tobacco, ujengi'a onweh.

The occurrence of mysterious and terrifying diseases which distorted the human body into but a semblance of the health and perfection in which it was created, may, in a way, account for some of the more ferocious and grotesque masks. To frighten the bearers of evil required the adoption of terror-spreading and are-inspiring means and methods. These masks of fearsome countenance, but of sacred usage, do not include those artificially grotesque falsefaces of modern manufacture used entirely for entertainment at public ceremonies or for sale.

The mask never was regarded as an idol-never the object of prayer or worship. But its intercession as a helper was dutifully invoked by those who beliered in the 
teaching and the promise of Shagodjiowe gow and the obligation imposed upon him by the supremacy of the All Powerful One.

That masks were not mentioned by early writers as being common among the Iroquois is no proof that their use is of comparatively recent date. It is probable that the first whites to come among them were never permitted to see a mask nor allowed to witness any of the more secret rites. Too, in those days it was considered a sacrilegious and criminal act to convey a mask to anyone not a member of the order. The finding of stone faces and small stone masks (pl. xiII) by archaeologists on early noncontact sites proves beyond doubt the ancient use of the gagolisa.

Many old masks have been destroyed by nembers of younger generations particularly by those converted to a faith which called them "devil faces," because they believed them omens of bad luck or that some mysterious, unknown power was vested in them. They frequently were held by the allegedly more progressive Indians, the "too-much-education-people," to be a hindrance to the practical pursuit of the ways and manners of so-called civilization.

As today much of the ancient ritual is forgotten or neglected and as many of the more important rites are either omitted or slighted, I am convinced that the present generation neither knows nor comprehends the mystic significance of the mask of old. Its earlier symptomatic meaning is lost and forgotten and its curative powers are no longer sought with the deep and abiding faith of their forefathers.

The intended office is incanted with offerings of the ujengrwa onzveh, and masks are used, but apparently not always with an appreciation of their essential featural 
types or knowledge of their mystic import. Yet, so I am informed. some Senecas. widely separated by space and time from their parent stem. use practically the identical mask meanings and employ ancient Falseface rites similar to those carried away by their migrant fathers long ago and indoctrinated through many succeeding generations. Note the Seneca Scalp mask illustrated (pl. $\mathrm{x}$ ) and the Cornhusk (pl. xiri) both from Oklahoma.

The old masks were carred with all the skill the maker possessed. and all the characteristic features prescribed for their intended offices and services were portrayed by conscientiously copring certain recognized patterns and models. It is for this reason that very similar representations, sometimes almost exact duplicates. are to be found in the older falsefaces.

The sacred mashs were those of great magic import whose powers were recognized among the Ongive Oiteka. the Old Believers of the Nations. Others were dance or beggar masks and were regarded as such much less seriously. There was also a belief at one time that masks of red, ikitestae gagohsa, either painted. stained or scorched, possessed much greater potency than all others. This probably accounts for the larger number of falsefaces of that color preserved from earlier generations.

Falsefaces colored a bright red and having notched ridges across the bridge of the nose and forehead were considered to possess an unusual strength of medicine power.

The workmanship in more modern masks is generally quite crude, often grotesque. Perhaps this reflects a lack of artistic ability. but much more probably it shows an absence of all the deep reverence and veneration that guided the fingers of their forefathers. 
Very modern masks, while carved from old models, are produced professionally, and generally for sale.

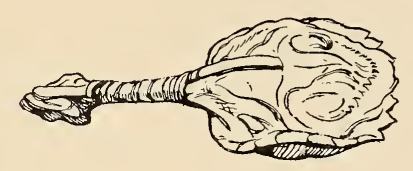

\section{THE SOCIETIES}

In former years great secrecy ever surrounded the convocations of the medicine societies. At the time of Ganiodeiyu the prophet, known to the English as Handsome Lake, who forbade all secret conclaves, including those of the medicine societies, meetings and observances were stealthily held despite his interdictions. Nowadays little secrecy is observed in conducting certain ceremonies forbidden by Ganiodeiyu.

The mask societies, as they exist today, have been reported upon by several students whose descriptions of them and their rituals are somewhat at variance. I have no knowledge of all of the many societies among the Iroquois, and so confine my comments to those about which I have exact information either from my own observations or from reliable and intelligent tribal informants.

I am given to believe that the Falseface Society, Hadi$g o^{n}$ sashoo $^{n}$, was the original group which took upon itself ministrations to the sick as individuals and invocations to the propitiation of malignant forces which might visit or were visiting their fury upon the whole tribe.

From this original group, offshoots or sub-groups sprang up as the centuries passed, each of these gaining or losing devotees, as generations came and went, depending upon the success of each in its approach to the problem it was called upon to solve, and the choice of the agency 
was often dictated or revealed to the sufferer in the course of a dream.

No doubt, through the years, medicine societies sprang up, flourished a while, and then disappeared so completely that no record of them exists. Although there are others. those of great antiquity that I know to be more widely recognized and which still exist are the Falseface Society proper, the Idos Society, and the Niganägaah.

Honunastesta, the appointed leader of the Falseface Society, was always a woman. She not alone led its processions, ganiadahjut, but she had charge of the regalia and was the only intermediary for communication with its nembers.

In public Falseface ceremonies the person who led the procession carried a decorated pole to which was attached a miniature falseface, a small cornhusk mask, and a miniature turtle-shell rattle as insignia of the order.

Because the whole social structure of the Iroquois, all its conceptions and executive functions. were based on the female principle, the appointment of a woman as Honunastesta is not to be considered unusual. Basically, the earth was looked upon as The Mother. The woman owned the land, lodge and children, and all hereditary rights descended through the maternal line. The clan's oldest woman always had the final dictum in directing any and all actions, and women had representation at all councils, enjoyed the right to make or abrogate treaties, and held the trusteeship of all tribal property. Further, they had the power to raise up or depose chiefs and to bestow clan names, the men merely having the right to confirm or reject such a choice. Thus it was by female prerogative that a chief came to represent both the men and women of their respective clans at all councils. Upon the return of successful war parties from among enemy villages, it was 
the women who had the right of adopting such captives as might be brought in, of saving their lives or decreeing death for them. In the redemption of an Iroquois woman taken captive or in considering the death recompense to be met in retaliation for the taking of her life, the value was twice that placed upon a man.

\section{THE LIVE MASK \\ Gallhadaligohlkatl gagohsa}

(PL. III)

Upon the occasion of some exceptional event in the life of the people, such as the crisis of an endemic disease, or the advent of a dire calamity, the Falseface Society sought an assured intervention against the evil influence and a restoration to health and good fortune in the potential power of the Live mask. The ceremonies preceding, during and subsequent to the making of this mask were considered of so important and sacred a nature that only the Honondiont. Keepers of the Faith, were qualified to officiate at them. Those eligible for this serious service were known for the sincerity of their zeal and for their chastity and prudence. Sexual intercourse was proscribed for a period both before and after the ceremony, and no menstruating woman was permitted to enter into the ritual. As in all similar medicine making ceremonies, the complete purification of both mind and body was basic and imperative; the secretory organs were purged and all carnal desires banished.

Those to whom had been assigned the duty of "asking" the life" selected a tree, preferably basswood, remarkable for its perfection of growth and for some days prior to the ceremony two of the group stood guard to protect it 
from possible contagion by contact with any influence whose ills and vices might be considered impure. The basswood, $\bar{o} \bar{o} s a$, was selected because it was considered to have many remedial virtues and because of the softness and absorbent properties of its fibre.

After the sacred tobacco was burned at its roots, the oldest member of the order, rubbing a turtle-shell rattle against its bark, addressed the tree reciting the ancient legend of the Shagodjiowengowa and the hunter and told the circumstances of the formation and great antiquity of the Falseface Society. After reaffirming the loyalty of its members to the traditional commandments, the tree was reverently requested to share and continue its life-spirit with the mask to be carved and hewn from its loins. The mask was then roughly outlined, and, as the carving was split away from the tree's trunk, the "wound in its body" was propitiated with incense from the sacred tobacco. The acquiescence of the tree to the appeal for a share of its life was affirmed by its remaining unshaken while the mask was hewn free. After the carving and decoration of the falseface were completed it was inducted into the Society with all the prescribed ceremonies that the occasion of so serious and unusual a service demanded.

Rubbing the turtle-shell rattle, ganohwa, upon the bark of a tree or against any wooden surface symbolically invoked its eternal life spirit and absorbed from it the mystic powers of both the "Below-" and "Above-world" which were connected by the Great Tree's deep roots and skyreaching branches. The Great Tree, gaindowane, was most important in Seneca beliefs. Its branches sheltered in peace and security, its trunk symbolized strength and unity, and its roots reached far and deep to the foundations of the earth supported on the carapace of the turtle. In 
death, the Seneca believed that the spirit of its fruits sustained his spirit in everlasting contentment and happiness.

Anciently the turtle-shell rattle was bound only with strips of bast or bark so that the fibre of The Great Tree might ever sustain its power. This, however, is no longer considered important as rattles are used today bound with ribbon, cord-even electrician's tape.

\section{THE DOCTOR OR MEDICINE MASK}

Ongwadedjä ${ }^{s h} \ddot{a}$ gagohsa

$$
\text { (PL. IV) }
$$

Doctor masks not only possessed the meritorious powers both of purification and of driving out disease, but they were highly respected in their ritualistic duties other than curative.

At public dance ceremonies of the Falseface Society the Doctor was the summoner who directed each member to dance as a devotional obligation. Should a member disregard the summons without good reason or should the dicta of the summoner be resisted, the matter might prove of grave and serious import. I am reliably informed of several instances in which the recalcitrants fell ill and eventually gave up their homes and removed to other reservations.

At the occasion of the New Year's ceremonies it was the duty of the Doctor, or, sometimes, another powerful mask, the Doorkeeper, hadehrvainoos gagohsa (pl. XII), to stir the embers and ashes and to distribute them to the four inner and outer corners of the dwelling, and to bless the newly kindled fire. They advised the people to forget the past year's disappointments and troubles and to forgive those who had trespassed against them, and expressed good 
wishes for the coming year for the health, happiness and general well-being of the entire household.

Doctors and, sometimes, Doorkeepers have at least one small bag of sacred tobacco attached to the fore-lock. These are left on after a ceremony in which they have participated and, to insure the continuance of their power and future potency regardless of the success or failure of their recent mission, another bag of tobacco is added at each ministration. It is quite common nowadays to find a number of bags attached to falsefaces indicating their active participation in different exorcising ceremonies, the number depending largely, I think, on the custom and usage of the times. Attached to ancient masks, long buried in the earth for purification, there are still found restiges of these small medicine bags.

In considering the primitive approach to the matter of curing disease, one must remember that the use of actual drugs as medications was considered decidedly of less inportance than the employment of magic formulae of sufficient potence to drive the evil spirits, thought to be the causes of the ailment, from the body of the sufferer.

Emetic and purgative potions were generally used as purifying agents preliminary to ritual ministrations, but in the employment of other remedies, more faith was placed in the manner in which their component ingredients reacted in preparation than to what effect these might have on the patient's system.

In combining the sacred medicine, gahnohgriahsehnah, and the water, in the curing ceremony of the Niganägaah Society, for example, the case under ministration was considered to be hopeless, even though the patient drank the preparation, if the three powdered heaps did not remain afloat during the ritual. 
To comprehend, therefore, the efficacy of the ministrations in a large number of cases and, sometimes, the sudden and complete cures recorded, one must not alone understand the value of a combination of faith and autosuggestion-quite widely recognized by present day physicians as most important elements in the patient's approach to his own illness-but must define the word "medicine" somewhat differently than do the trained disciples of Aesculapius.

Medicine, among the Iroquois, was considered to be the mysterious quality and manifestation of spiritual power, whether by curative potion or through the invocation of supernatural phenomena, strengthened by the intercession of the personal orenda of the supplicant.

Previous to the ceremonial visit of the medicine man there was a purification observance during which the patient submitted to a vigorous treatment by purges and emetics after which he was not permitted to touch or come in contact with any unclean or greasy thing until the completion of the ceremony. After treatment the patient was allowed to partake only of the light meat of white-coated animals or white-feathered fowl.

When the Falseface procession entered the dwelling of the sick, the medicine men formed a circle and hung a series of blankets, preferably white, around the patient while the Initiatory mask offered the incense of the ujengwa onach at the council of administration in the sick room. During the ceremony, the gatsissa or Cornhusk mask guarded the doorway.

In order to exorcise the evil spirits and to call out the pain they were causing, the Doctors would take handfuls of live embers and hot ashes from the hearth. Some of these would be blown upon the patient by the masks with spread-out lips, " those upon which evil cannot rest," and 
the balance were rubbed upon the afflicted body area. This service was also rendered to patients publicly at the time of the New Year's feast.

Anciently, I was informed, all the Medicine Animals to whose spirits the chant, ganoldda, was sung were represented in the ministrations of the Niganägaall by appropriate masks. Nowadays, howerer, falsefaces are no longer employed by that Society. Another characteristic difference is to be noted in the respective ceremonials of these groups. While the Idos and Niganägaah use only properly pitched gourd rattles, the Falseface Society proper excludes these and employs the turtle-shell, ganolicia, and the hickory-bark, osnol ganohwa, rattles, filled with wild cherry pits.

Originally the ritual, a sort of incantation by the Head or Guardian mask, invoked the spirit of Shagodjioi' ${ }^{\prime}$ gori'a to restore peace and health to the sufferer. At the time of this chant, the evil spirits were exorcised by light manipulation orer the affected part and by the ceremonial blowing and rubbing of ashes upon it.

Should the patient be unable to stand, the " Upholders" supported him in an erect position. At the approach of death the function of these " Upholders" was considered to be of vital importance. To keep the person erect, thus signifying that he was above ground and, so, on earth. was one of the prime requirements of the ritual, and expiring chiefs. dressed in full regalia of office, have been sometimes patiently thus held through many hours so that they might be " on their feet " as life finally left them. To stand " on their feet" indicated strength and courage, qualities enhancing not only the potency of that particular chieftainship, but proving the bravery and fortitude of its bearer.

It was considered most important by the Iroquois that a chieftainship should not become extinguished by the pass- 
ing away of its incumbent. For this reason dying chiefs or those going to war or about to engage upon some hazardous undertaking handed back to the clan, or " hung up " their "horns," onagashon a, so that their office and name might remain alive to be bestowed upon some chosen successor. It is thus that ancient chieftainships have been carried down through countless generations of the Iroquois and that, by non-observance of this custom, some have become lost.

\section{THE MATERNITY MASK}

(PL. V)

Early in pregnancy, the expectant mother was presented with a small maternity mask of wood, owengeah gaysgahdo gagohsa, or of stone, gatsgallyiegoh gagohsa (pl. XiII), during ritualistic incantations for her strength and wellbeing. This she thenceforth wore between her breasts as a talismanic charm, close to the new life it protected to avert evil influences and insure a safe delivery.

During the entire period of her pregnancy the woman meditated upon the richness of the privilege that she was soon to enjoy and directed her thoughts to the beauties of nature, to the birds and the flowers, to the agility of the fleet and the power of the strong, and to the virtues of an ideal life so that these might all become a part of her child's nature.

As Indian women would sometimes be alone through the actual ordeal of delivery, ceremonies pertaining to the birth occurred prior and following parturition.

Through incantation of the Maternity mask prior to and during actual birth, the spirit of evil was propitiated, and upon promises or vows made by the expectant mother, the mediators of the Great Spirit were asked to bless the new life and to invest it with all that is brave and good. 
At the pre-birth ritual, the talismanic infant falseface was taken from the mother and attached. with the bag of sacred tobacco, to the forelock of the officiating mask, that it, too, might absorb its potency. This masquette, together with the umbilical cord. was later attached to the cradleboard through the child's infancy and preserved throughout the life of the individual.

The lips of the true maternity mask were expanded at either corner into hollow discs, a feature most characteristic of this class of falseface. At the actual time of birth the Spirit of Life rested with that of Death in these hollows or " cradles," and the supremacy of one over the other was considered to be an immediate matter of the spiritual strength or weakness of the orenda of the woman. The magic power of the gagolisa and the strength of its secret medicine decided the issue in that crucial hour.

In the case of a premature birth, the duty of the Maternity mask was even of greater gravity inasmuch as its requiem chant was believed to assist in the completion of the undereloped soul. The premature child was considered as reverently as the full-term, and, if born dead, was buried with all customary ceremony. During the full lactation period, the mother visited its grave and, squeezing the milk from her breasts upon it. fed the spirit of the departed. Should the child die immediately after birth, a small mask was buried with it. These have been exhumed with the bones of infants.

\section{THE FEMALE MASK}

(FRONTISPIECE：PL. VI)

The Female mask, symbolic of the safe delivery of a male child, differed essentially from the maternity masks which officiated prior to the onset of labor, and expressed 
the reverent thanks of the mother for the magic power to bear male children, particularly those who might one day come to be great chieftains and warriors of the nation.

These masks are distinguished from all others by their having ears, a characteristic which denoted the female to be quicker of alarm than the male. This is a fact but recently verified by science which has come to realize that in the female of all animal genera the special senses peculiar to each species are more highly developed, perhaps as a protection to herself and her young in compensation for a lack of the greater and more valorous strength of the male.

In the New Year's ritual where thanks for the creation of all things were so fully given in the Thanksgiving Chant, the supreme gift of female fertility and the virtue of continuance of the race were especially emphasized. The Female mask was then worn by male impersonators who affected progressive states of pregnancy through various parts of the ceremony. This practice is now being rapidly abolished through the efforts of missionaries.

\section{THE COUNSELOR OR HUSH MASK}

\section{(PL. VII)}

The Counselor in time of war warned the people of the possible approach of an enemy; in council it quelled any disturbance arising from oratorical harangues, discussions or disputes that might have led to serious controversy or possible rupture; in peace it advised quiet, calmness and dignity of manner; in pleasure it counseled a moderation in the display of joy and gratitude, and cautiously warned against excesses among a people some of whom were given to quick and ebullient ecstasies. 


\section{THE DANCING BEGGAR MASK}

\section{Hahyeahgranis gagolisa}

(PL. VIII)

The Beggar mask found its sole purpose in amusement. This consisted mainly in comic dancing-really a grotesque hopping-while chanting his guttural call "/looo hooo hooo:" and begging gifts of tobacco. If his plea was granted, he danced in rhythmic accompaniment to the holgohsoliskahahgilnoh sung by the donor who beat the ground with a turtle-shell rattle handed him by the maskwearer. He not only danced to the Beggar Falseface song in the Long House, but in private dwellings at the time of the New Year's ceremonies.

In times of dire distress, urgent necessity or extreme porerty dance masks have been used, in rare instances, in place of medicine or other sacred masks. In these cases they were appealed to, the exigency of the owner's plight explained, and the ujengrid onwel attached, with the same reverence and sincerity that would have been shown a Doctor, or other sacred falseface.

\section{THE HARIEST MASK}

\section{(PL. IX)}

The Harrest mask, decorated with cornhusk plumes and streamers, was the placid interpreter of the fulfillment of the harvest. In the song-service to the Honotschinnogän, the spirits of the animals, he represented one rerse in which gratitude was expressed to the Great Maker of All for the blessing of a bountiful harvest, for the draping of Mother Earth in her glorious mantle of green, for her red fruits and for the enrichment of her children by the Three Sisters, Deoliako, the bean, squash and corn. 
So solicitous and reverent were these people for the promise and fulfillment of the harvests that just before the feast of the Planting Festival it was the custom of the matrons to select from among the various clans the purest and most attractive maiden who, at nightfall, would divest herself of clothing and walk over the fields imploring that they freely loan to the waiting seed the fructifying warmth and sustenance of the Earth Mother's flesh. At the important Harvest or Thanksgiving Festival it was her privilege to name the male speaker and the Honondiont to officiate at the ensuing rites. If the harvests were not plentiful, she would disappear and hide like a wounded animal, fearful not only of the disappointment of the people, but alarmed and dejected that Hodiänokdoon Hediohe had refused to answer her prayers. She felt misfortune had visited her people due to a lack of earnestness or of scrupulous sincerity in her invocation, and knew that some question as to her virtue and purity might be raised among them.

During the threat of drought, the sacred tobacco was burned to the Harvest mask and it was implored to intercede with Hēno, the Spirit of Thunder, or to call upon Ashadageah, the great invisible Sky Eagle. This legendary bird, flying through all eternity, caused the fall of night by opening its wings and the return of day by folding them. It carried a lake in the hollow of its back the water from which, filtering through the pinions, fell upon the earth as life-giving dew.

The lack of interest in commercial farming has often been charged to laziness on the part of the Indian. This is largely not true.

The Indian cultivated only small patches of garden that would supply sufficient harvest for his own needs. The 
Old Believers could not be induced to cut the "skin" of their Earth Mother with a steel plow in preparing the fields for planting, nor could she be asked to yield the milk of her body, except in quantity required to sustain the lives of her children, without forcing her into virtual prostitution.

\section{THE LALGHING DANCER MASK}

\section{(FRONTISPIECE)}

The Laughing Dancer or Happy Hunter illustrated is a very old Seneca mask. It always represented some event of unusual joyfulness. The buffalo horns and the cap are symbolic of happiness, as the buffalo hunter was supposed to be ever cheerful and happy, blessed with well-being and possessing great generosity. This particular mask is carved from a hard wood, so chosen, no doubt, because the absorbent qualities of a Medicine mask were not required by this Dancer.

\section{THE WIND MASK}

$$
\text { (PL. X) }
$$

The Wind mask was called upon either to placate the ravages of violent storms or to help invoke the aid of the winds to bring the soft beneficial rains that would not alone cause the seed to germinate and sprout, but wash away and make sweet all the earth-things after the battle of Heno, The Thunderer, with the monsters and ogres of disease, pestilence and death.

At the New Year's Festival the Wind mask just at dawn was called upon to invoke the breezes to fructify the earth by dispersing the pollen and seed of all the useful plants. 
THE SCALP MASK

(PL. X)

The Scalp mask was worn upon the return of a war party at one of the dances in the triumphal celebration of the success of a victory or conquest.

As the reputations of the young warriors depended largely upon the scalps taken, these trophies were proudly exhibited to all the people as proofs of valor, before they were offered in solemn sacrifice to the spirits of their erstwhile owners. It was felt that to take a human life required expiation, and therefore, once the celebration of victory was completed, sacred and solemn rites of atonement were held for the purification of those warriors who had achieved valor on the field of battle.

\section{THE AVENGING SCALP MASK}

\section{(FRONTISPIECE)}

The services of the Avenging Scalp mask were used to express retaliation for some personal or tribal wrong usually by an older warrior whose long brooding over the matter increased the savagery of his nature and led him to a contemplation of crueler methods of revenge than the simpler forms of battle duty. This mask, too, appeased the spirit of a slain woman by the redemption of a vow to avenge the premature cessation of her fruitful and useful life.

\section{THE CLAN MASK}

$$
\text { (PL. XI) }
$$

Clan masks represented their respective divisions at certain lodge convocations and at important ceremonies to the Honotschinnog $\ddot{a}^{n}$. Although, obvionsly, there must 
Inve betm a number of such falsefaces, to my hromledze that ilinstratel is the omly such masts in existence.

It is a Molf Gan mask collecteif in Camada, and, it it was mot taken there gersomally by Tosepln Brant when he

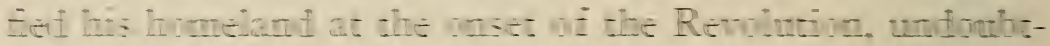
Eilly was in the custody of one of his followers. It is my personal iething that Bramb. aithough he became Christianizef. Heep domm in his heart afhereil to the mostio hetiets of his people.

I have lowown Indian converts to Christiamitu. some of them chuech oficers. who ovutinued on artend and partictpate in the rites of secret medicine societits.

\section{THE COMPLETING MASK}

\section{FL TII}

The Lompleting mast ofiociater at the end of the feast ai the Falsetace Soctert. Its black owhe supgrests the mostertes of the might and the silences of to shodoms.

That illusurated is a venerable falseface fating back to the ocoupation of the Geneser Vallery by the Beneca. It was vriginally a Macermity mask which offeciated at the onsumumation of a successful birth. It is probuble that bechuse this particular masis hal gained an especially notable reputanu for beneident achiewement. it was chosen as a ponerful meiliator tonord the culmimation of decisive events as a powreriul aid to thent succesiful onnchusive.

\section{ANIMAL AND BIRD MCASTS}

Antemtiy. amimal faliefaces representing clan totems were emploved in certain rites. In carving such masks often only soue butstaming characteristic of the animal was strgereserl. tho atcempt being mavie to provituce an actual likenes: of the birel or least. 
The Pig or Boar mask is a modern substitute for the more ancient Bear, and when it is used today it still represents the latter although the feast in which it participates rarely includes bear meat.

In ceremonies, the Bird mask (pl. Ix) simulated the actions of the Feathered Tribe by moving its arms in a winglike flapping manner and stooping over as if picking at food. This pantomime not alone represented a summons to the feast, but was considered an act of tribute and homage to the denizens of the air.

This was deemed a most praiseworthy and salutary procedure, for it encouraged the continued assistance of the winged population of the fields and forests in the destruction of enemies to the crops. The little songsters were thanked for their cheering voices, and deference was expressed to the eagle, crow, hawk and owl, all recognized to be members of the Niganägaah.

This Society recognized the spirits of the dead, as well as those of the live, animals. Among its members the Crow mask, being the enemy of grubs, mice and insects which devour planted seeds and the roots of growing things, was held in such high esteem that it was constituted the announcer of the feast and an important partaker of its service.

\section{THE CORNHUSK MASK}

\section{Gatsissa \\ (PL. XIII)}

Though these comments have purposely been centered on the carved wooden masks of the Iroquois, it is necessary that some short mention be made of the Cornhusk.

These masks, being woven or sewn of braided cornhusks, probably indicated the fruitfulness of the harvest, their 
radiating streamers, in all likelihood, suggesting the warming rays of the life-giring sun.

The Cornhusk guarded the door during the ministrations of the Doctors and waited at the threshold until the medicine procession had filed from the room. During this rigil it maintained a continued chant. imploring peace upon the sick and a speedy restoration to health.

These masks also acted as the guardians of the men's and women's doors of the Long House during important conferences or ceremonies. They stood at the exits and demanded an offering from each person who left the convocation. Usually, the gatsissa required a gift of tobacco, a double quantity being the penalty for leaving the conference permanently. These masks also figured importantly at the New Year's feast, a ceremony not to be confused with the white man's New lear either by date or manner of celebration.

Among the Iroquois the occasion, its occurrence in midwinter depending upon the phase of the moon, really constituted a nine day period of thanksgiving. Religious ceremonies commenced early each day, with the strength of the ascending sum, and ended at noon. Social gatherings and Beggar mask dances were held through the afternoon or at night.

\section{TREATMENT OF MASKS}

Medicine, exorcising and sacred masks when not in use were kept. preferably; wrapped in white cloth, with a turtleshell rattle close by. Doctor masks were frequentlyscraped before purification and administration rituals and then repainted. Thus, in time, some were reduced to mere shells and were usually buried in the earth or boxed away under their ormer's lodge. 
Masks were said to "sweat" if improperly treated or scoffed at. Dire consequences, it is related, ensued to punish the disrespectful and the scurrilous. To propitiate masks thus afflicted, the sacred tobacco was burned for them and they were offered a sacred pudding which had absorbed the spirit of the offered ceremonial and thus acted to strengthen their spirit and their inherent power for good. Appeals were made to them for forgiveness, and they were reverently implored not to express further displeasure and dissatisfaction by doing harm or bringing illness or bad luck.

When a mask was "poisoned" by the presence of some evil influence, expressed, for instance, in drunkenness, uncontrolled passion, or violent temper, it was scraped with a white stone knife and kept in "hiding" until it was believed to have been purified by its seclusion, or until all ill effects were thought to have worn away through the penitence of the offending party. A mask so poisoned was known as odgoh gahneegondah goh.

In more modern times, when a falseface of importance, such as a Doctor or a Doorkeeper, was transferred to the keeping of another person, the fragrant smoke of the sacred tobacco arose from glowing embers as words of consolation, admonition and goodwill, and prayers for the protection of the mask and its new owner were feelingly spoken.

The mask was promised that the new home was to be a good one, its approval of the transfer was asked, and its intervention for good luck was fervently sought.

The use of the ujengre'a onweh and its incense consecrated this action and constituted it a sacred religions ceremony. A small bag of sacred tobacco was then attached to the falseface, partly to appease, partly to insure its future goodwill and the preservation of its inherent powers. 
Most of the foregoing information was imparted and entrusted to me many years ago by the Seneca men and women who were of sufficient age at the time of The Grandfathers to have remembered much of the ancient beliefs many of which are now changed or forgotten. As my own shadows lengthen I am actuated to record, at last. some of the imagery and the observances of the Iroquois of old solely to preserve from almost certain oblivion the beauties of their philosophy. I feel. somehow. that the spirits of Indian men and women who were my preceptors and confidants will approve my motive. no matter how feeble and inadequate its expression. and that they who are gone know that these notes on the esoteric parts of their natures, these sincere recordings of their deroutness and faith. are made to help " those-who-follow" to a fuller understanding of the glory that was the Iroquois.

- All that may be told of the mystic properties and practices of the gagolisa is here related. The deeper secrets remain as sacred to me as they were to those who intrusted me with them.

May the many admirable qualities of heart and mind of the people who adopted me endear their memory to the reader of these " talking leaves." may they gain his sympathy and love, and may they create in him a better understanding of. and a more gracious affection for. all of the children of the Great Maker of All.

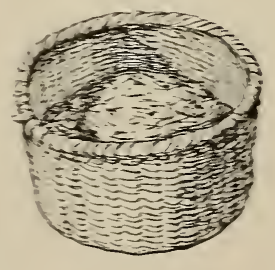


PLATES 


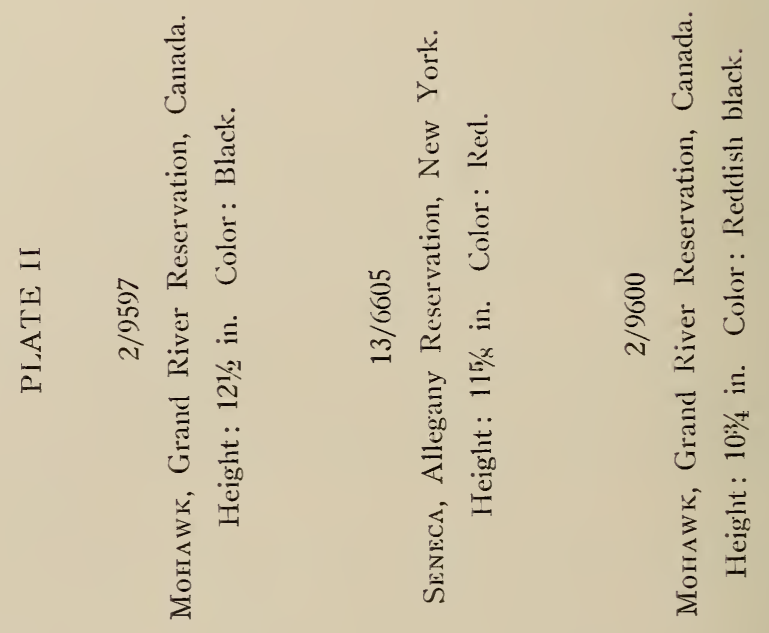


$=$
$\frac{\omega}{ \pm}$
$\frac{5}{a}$
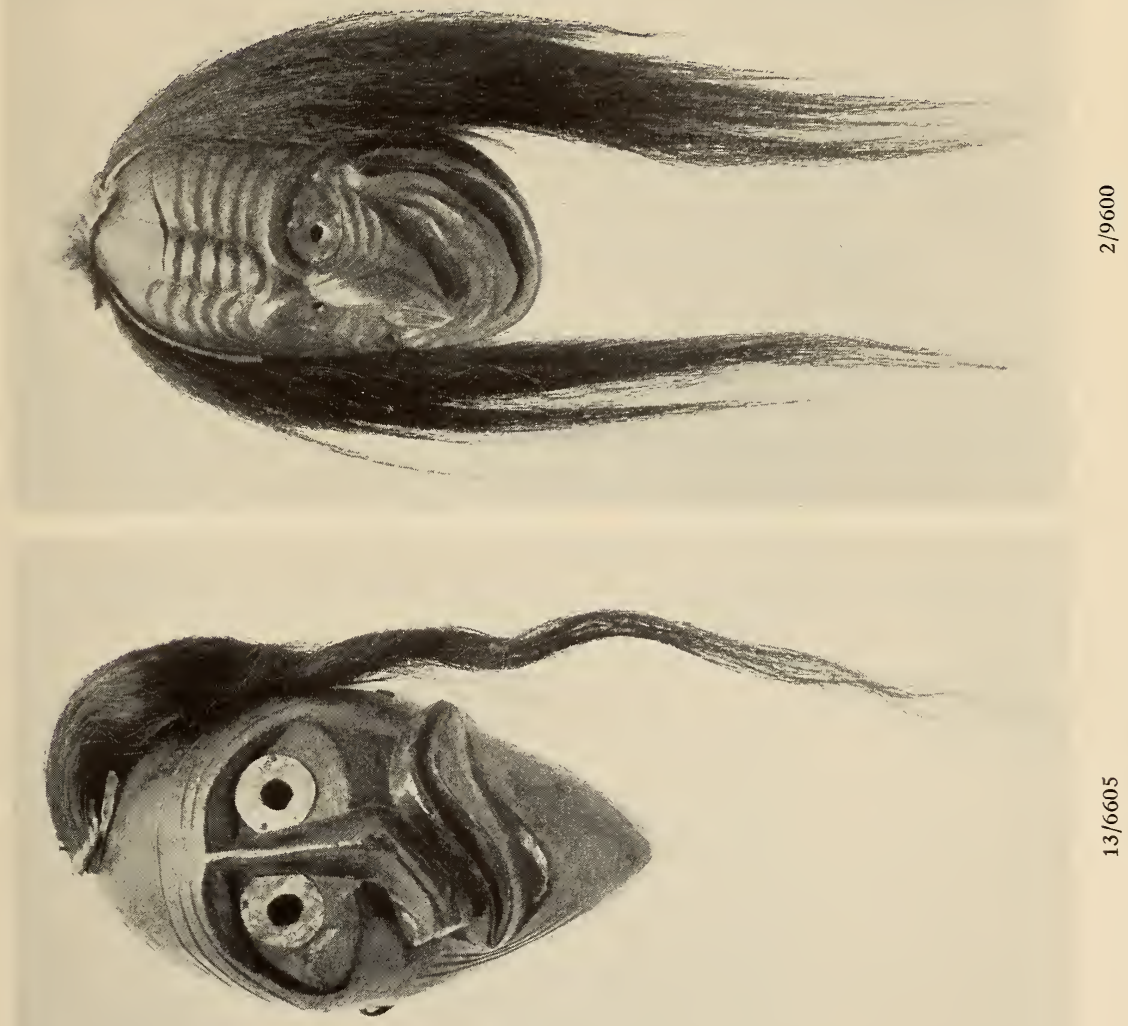

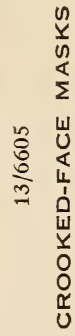

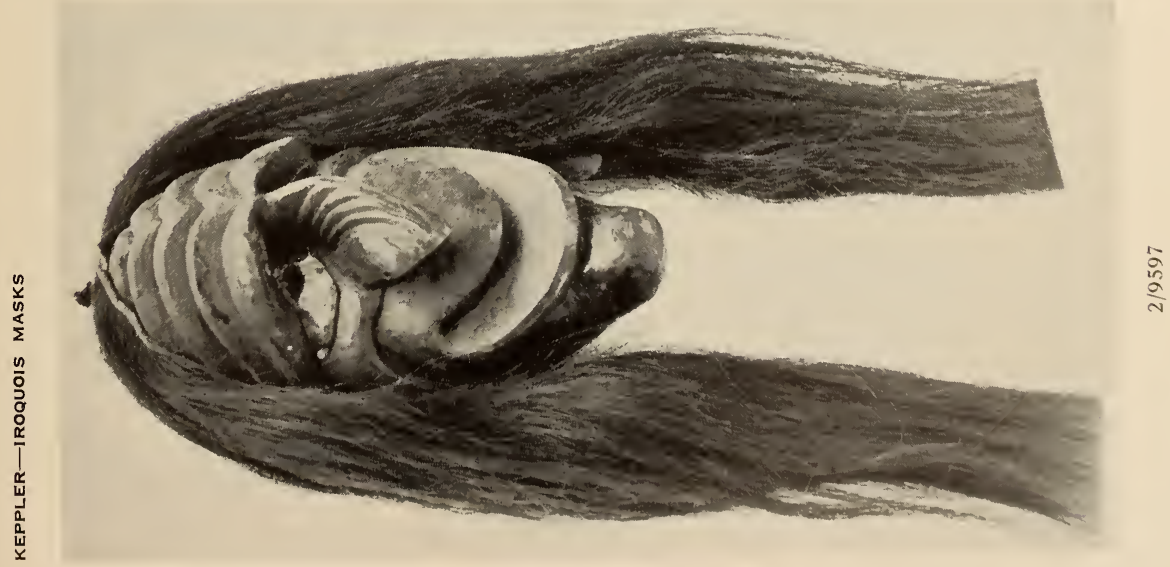




\section{PLATE III}

\section{$18 / 8655$}

Seneca, Cattaraugus Reservation, New York.

Height: $103 \frac{3}{4}$ in. Color: Natural wood. 


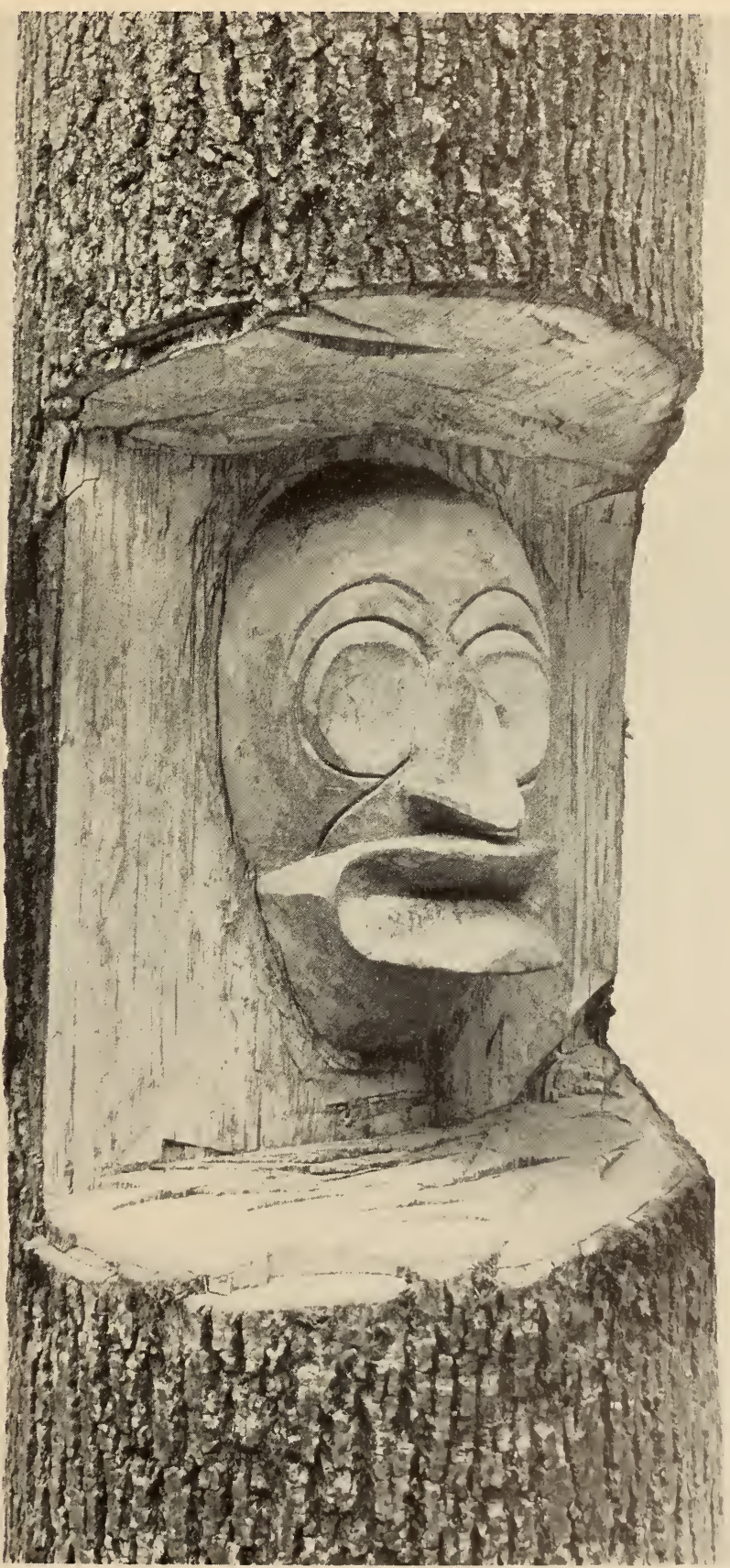

$18 / 8655$

LIVE MASK 


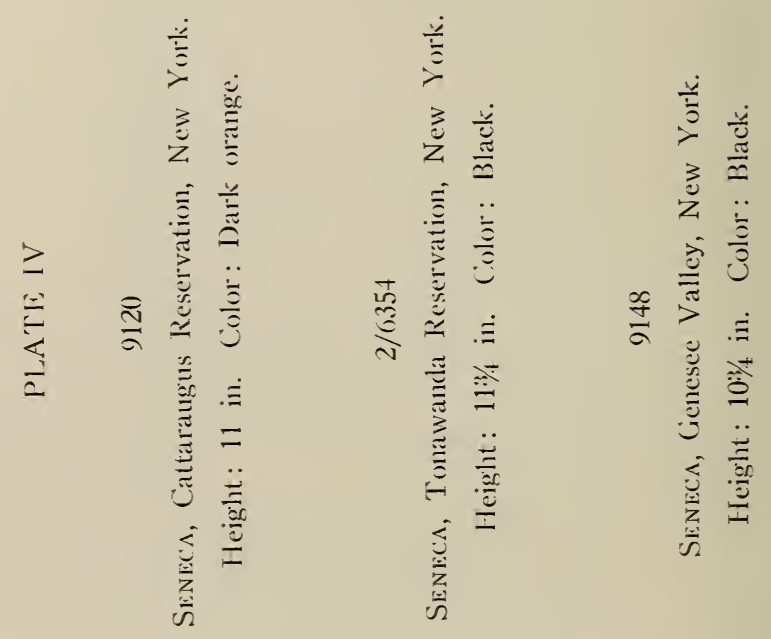


$\geq$
$\frac{5}{5}$
$\frac{5}{2}$

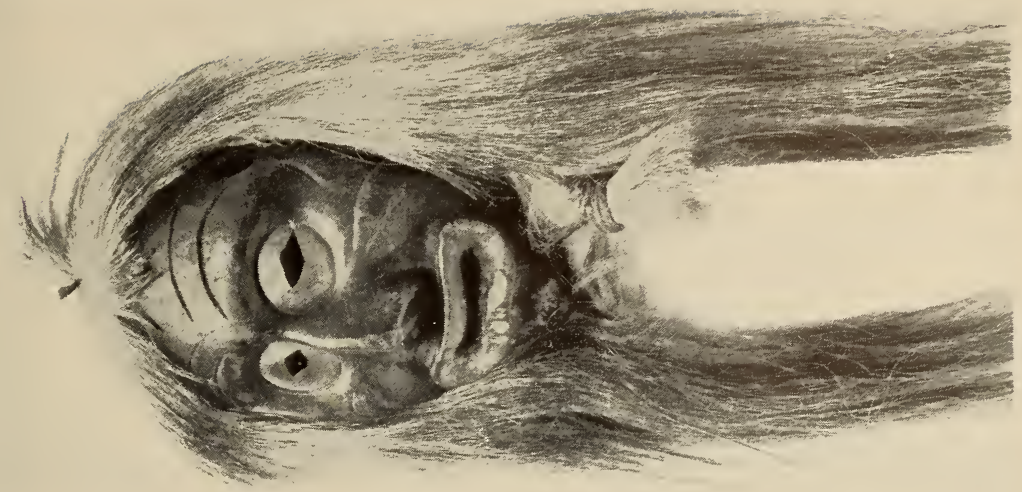

$\stackrel{\infty}{+}$

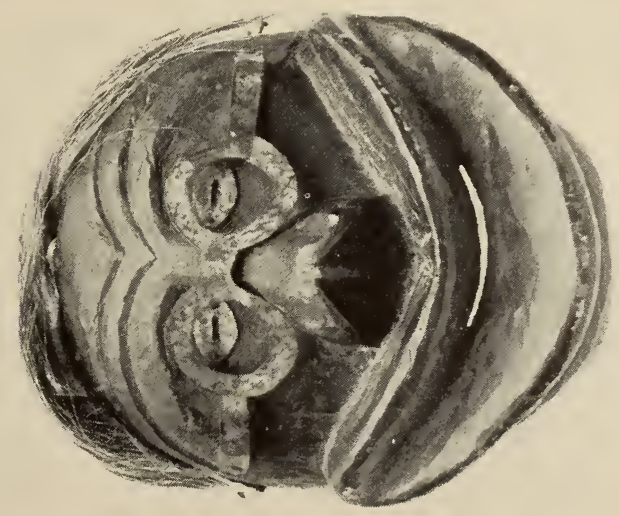

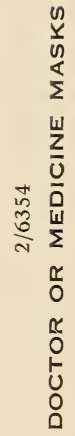




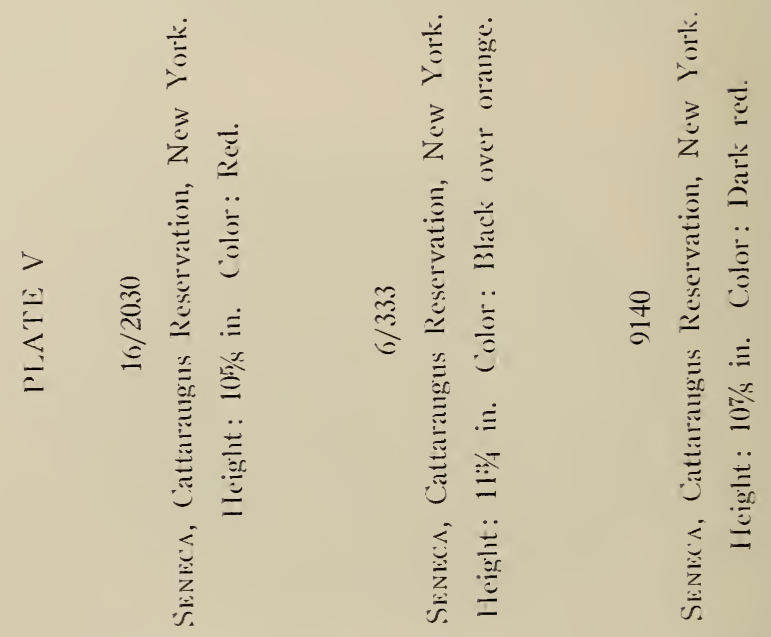




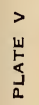

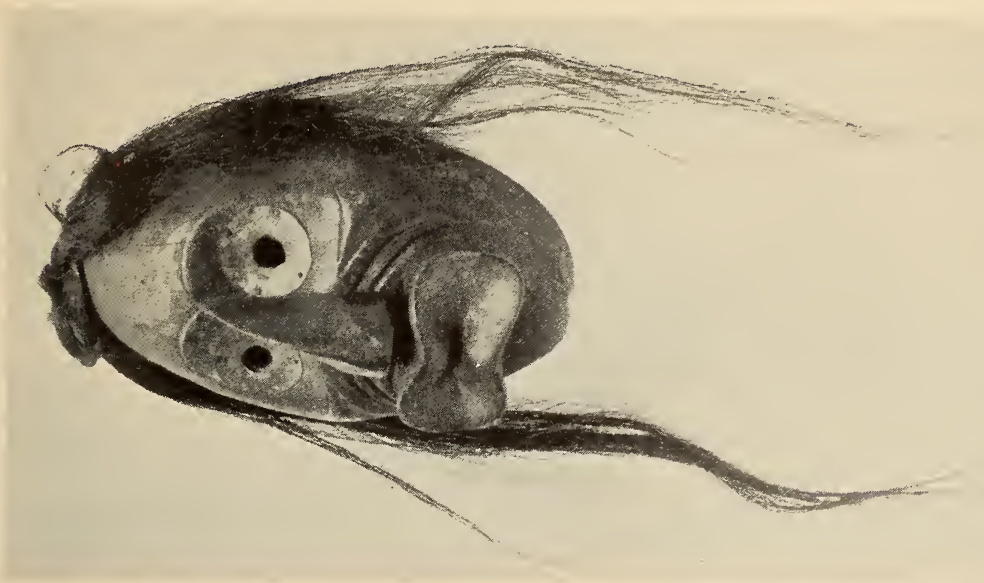

웃

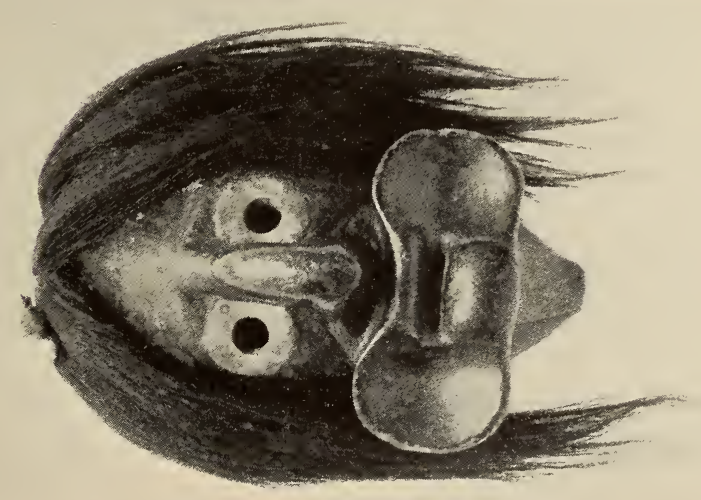

$\frac{n}{n} \frac{n}{n}$

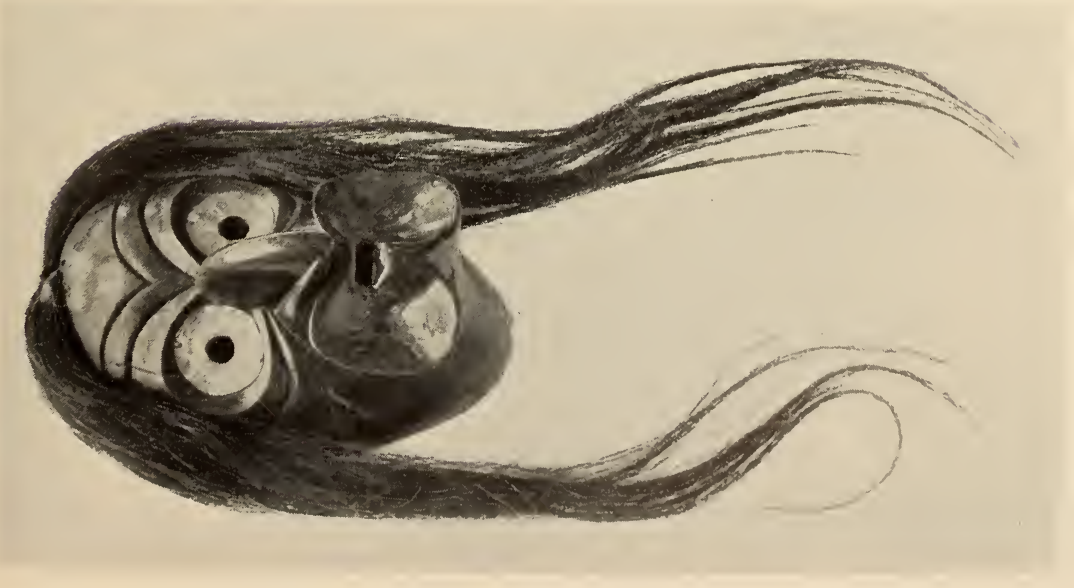

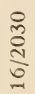




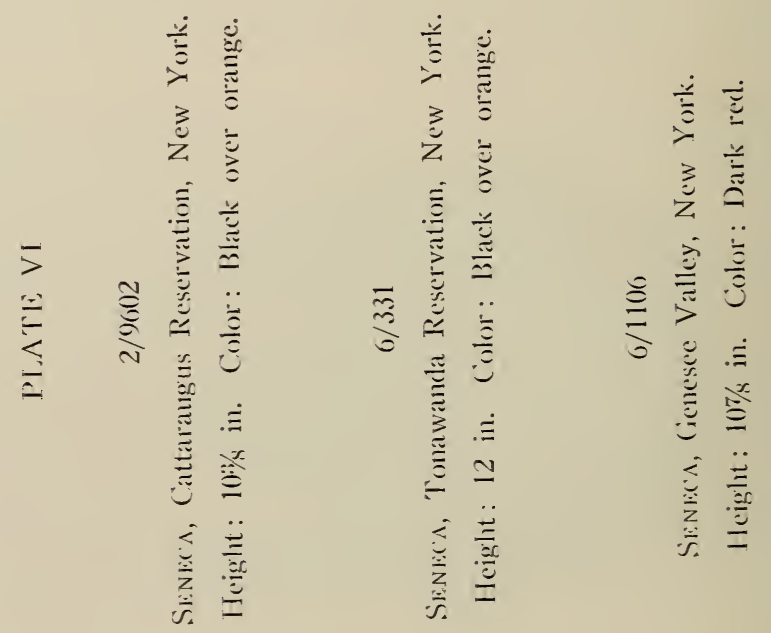




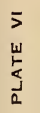
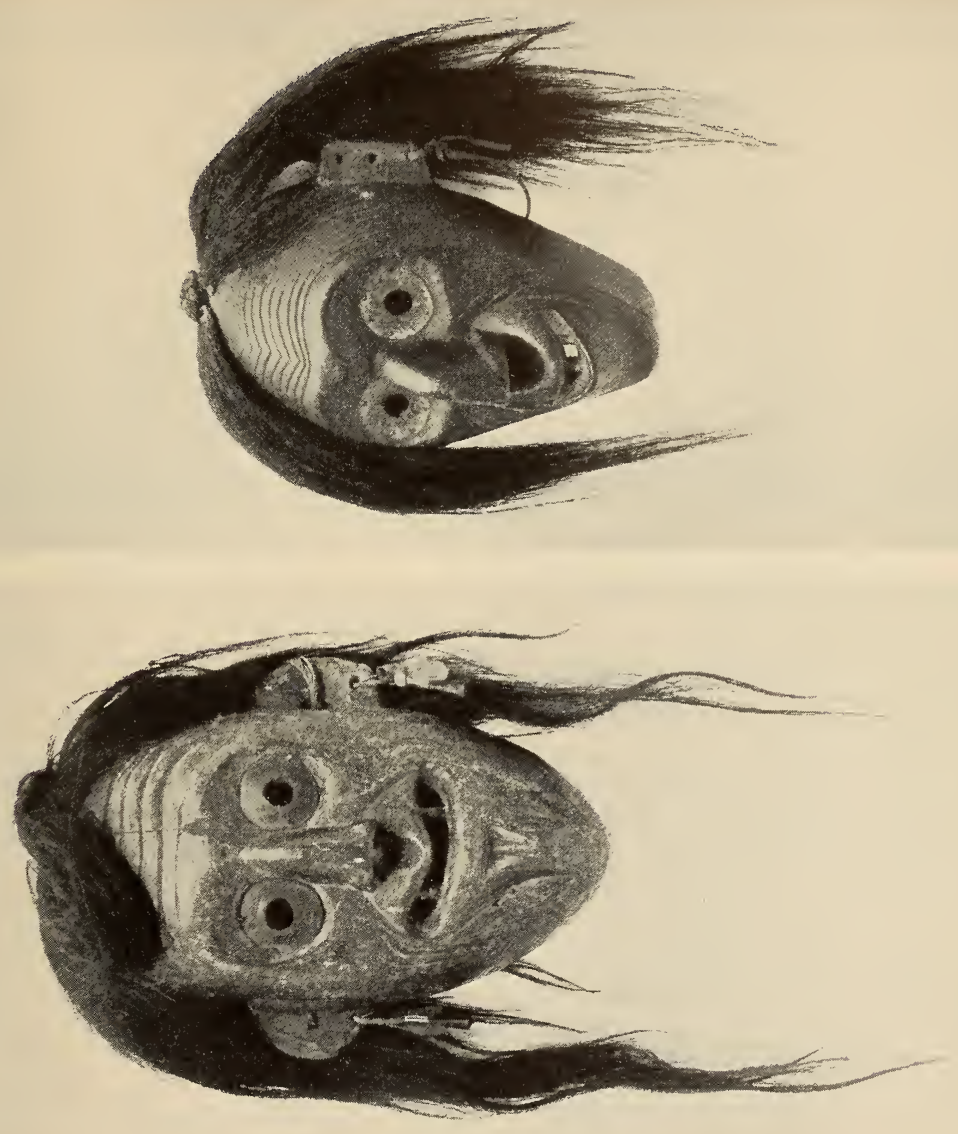

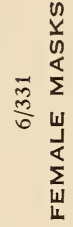

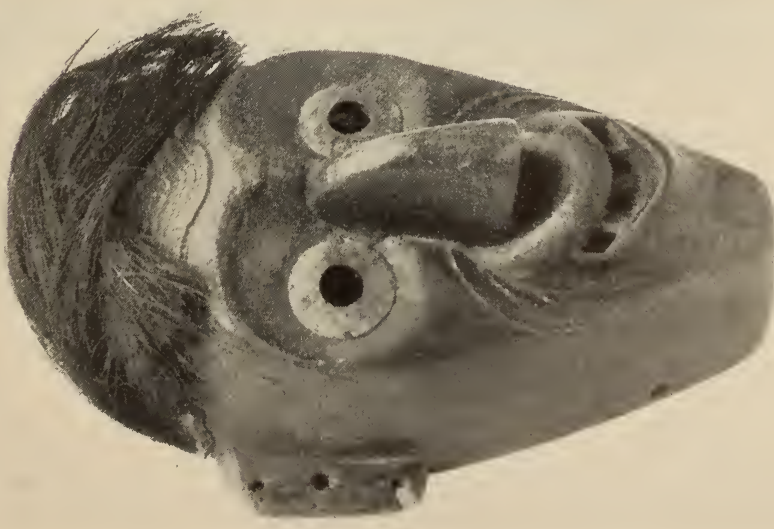

ปั่ 


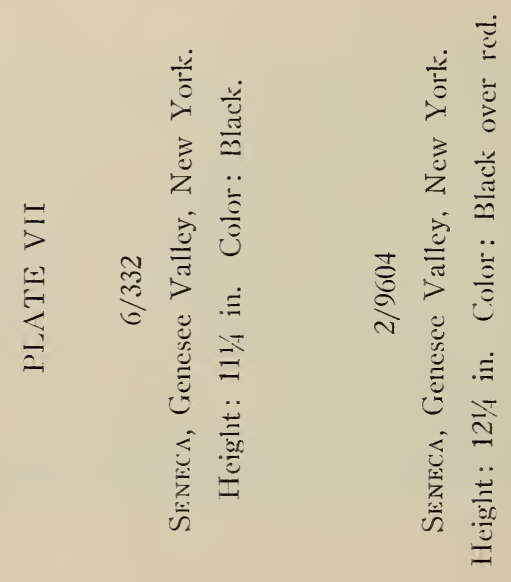


5
$\frac{5}{5}$
$\vdots$
$a$
$a$
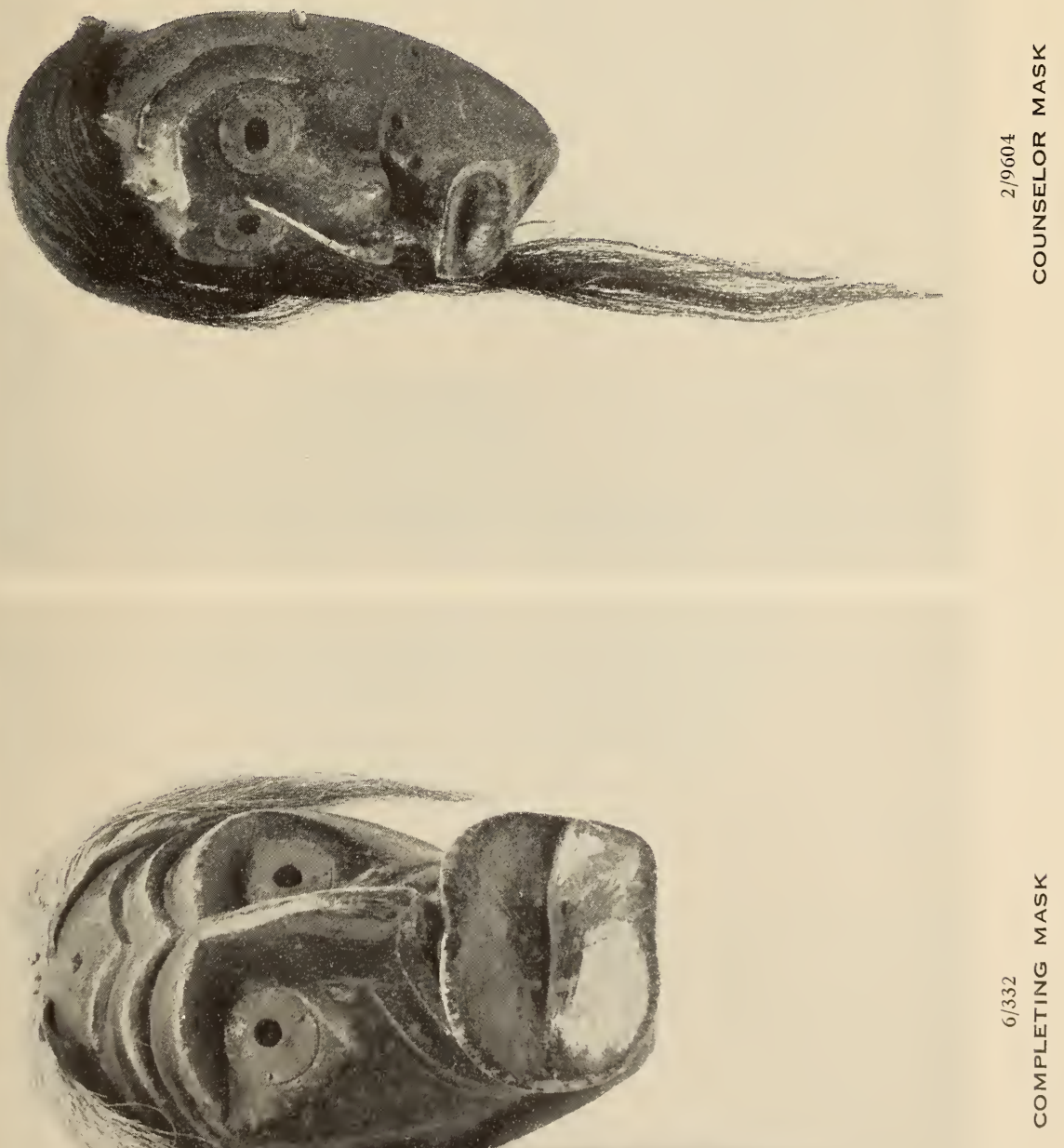

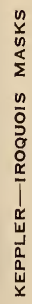




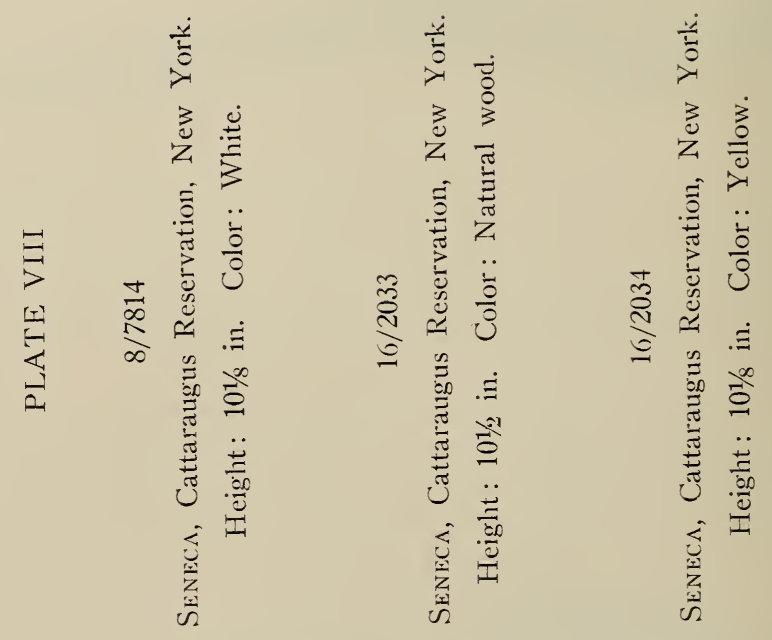




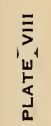

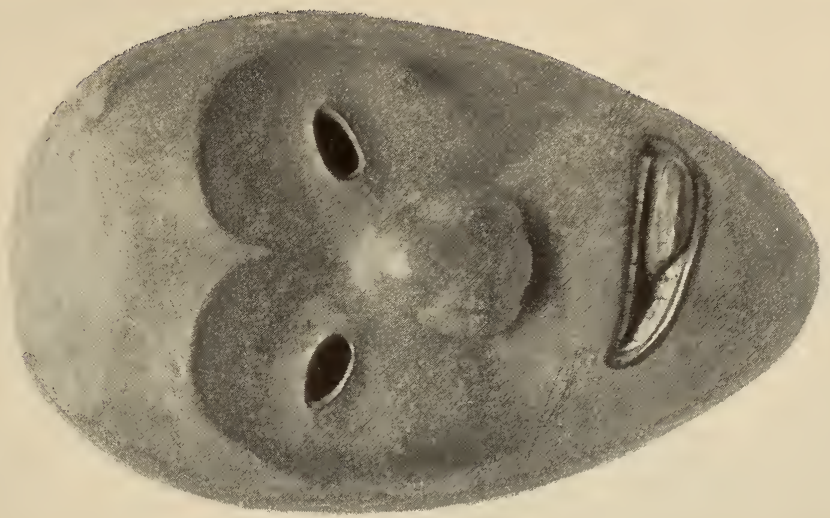

$\frac{+}{2}$

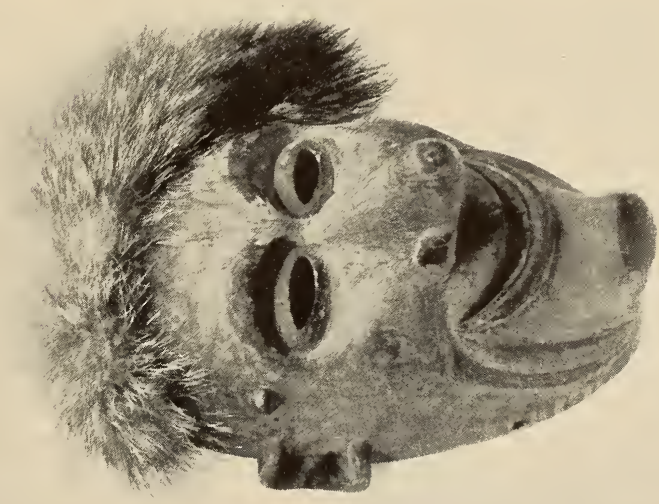

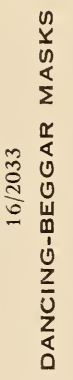

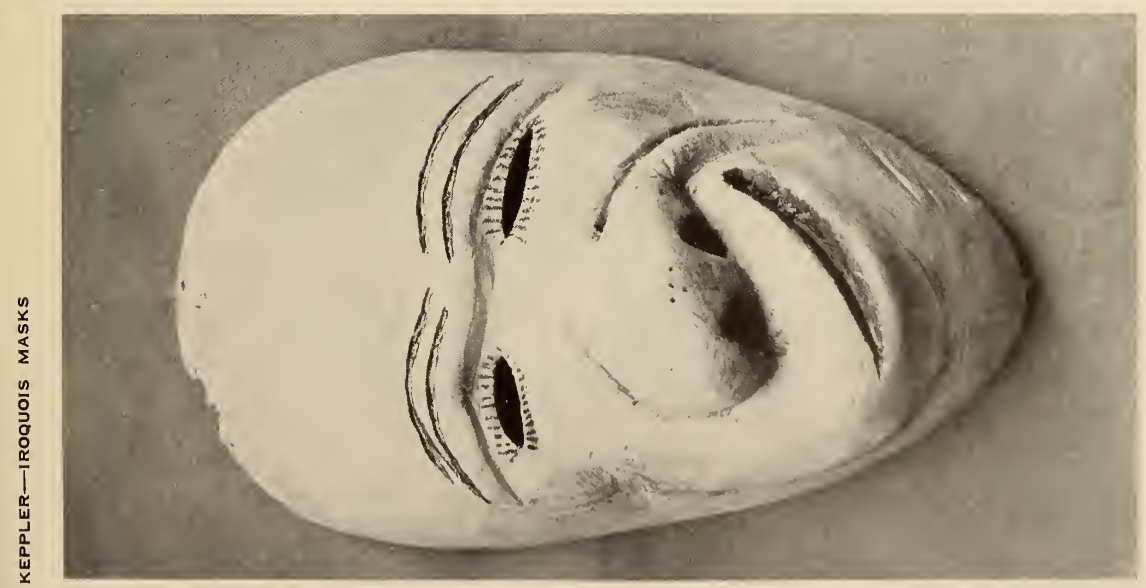

$\frac{ \pm}{\frac{x}{x}}$ 


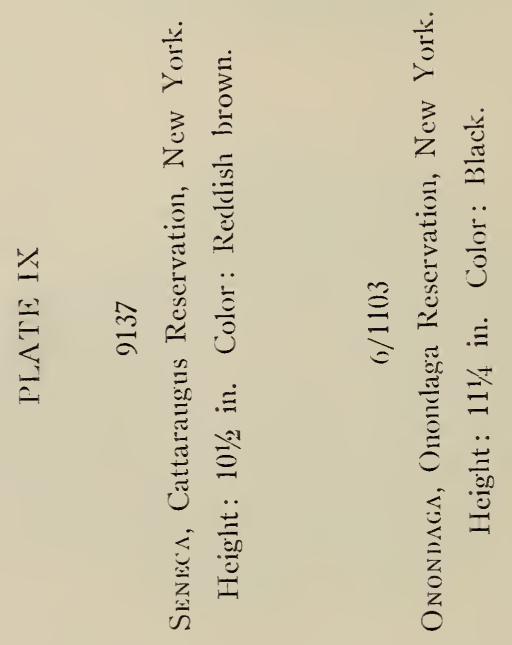




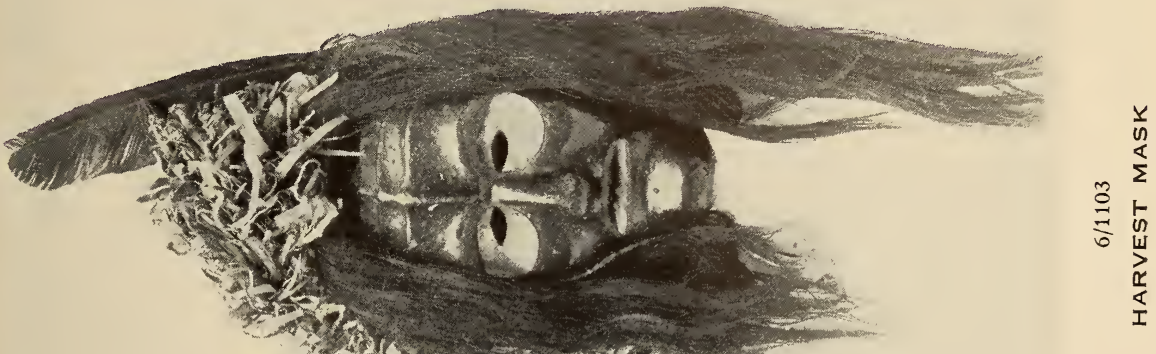

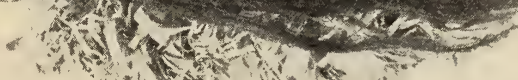

2.

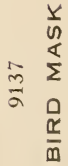

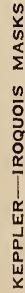




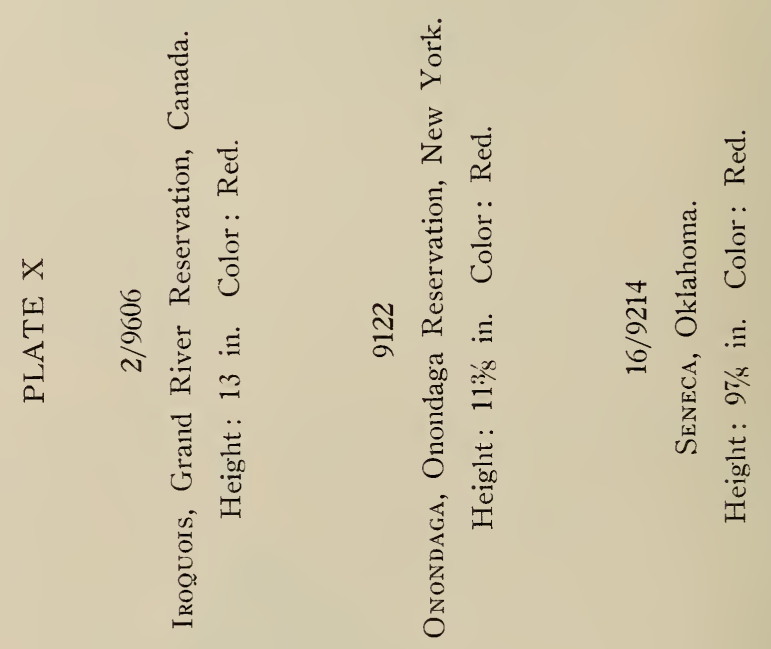


$x$
岁
$\frac{5}{5}$
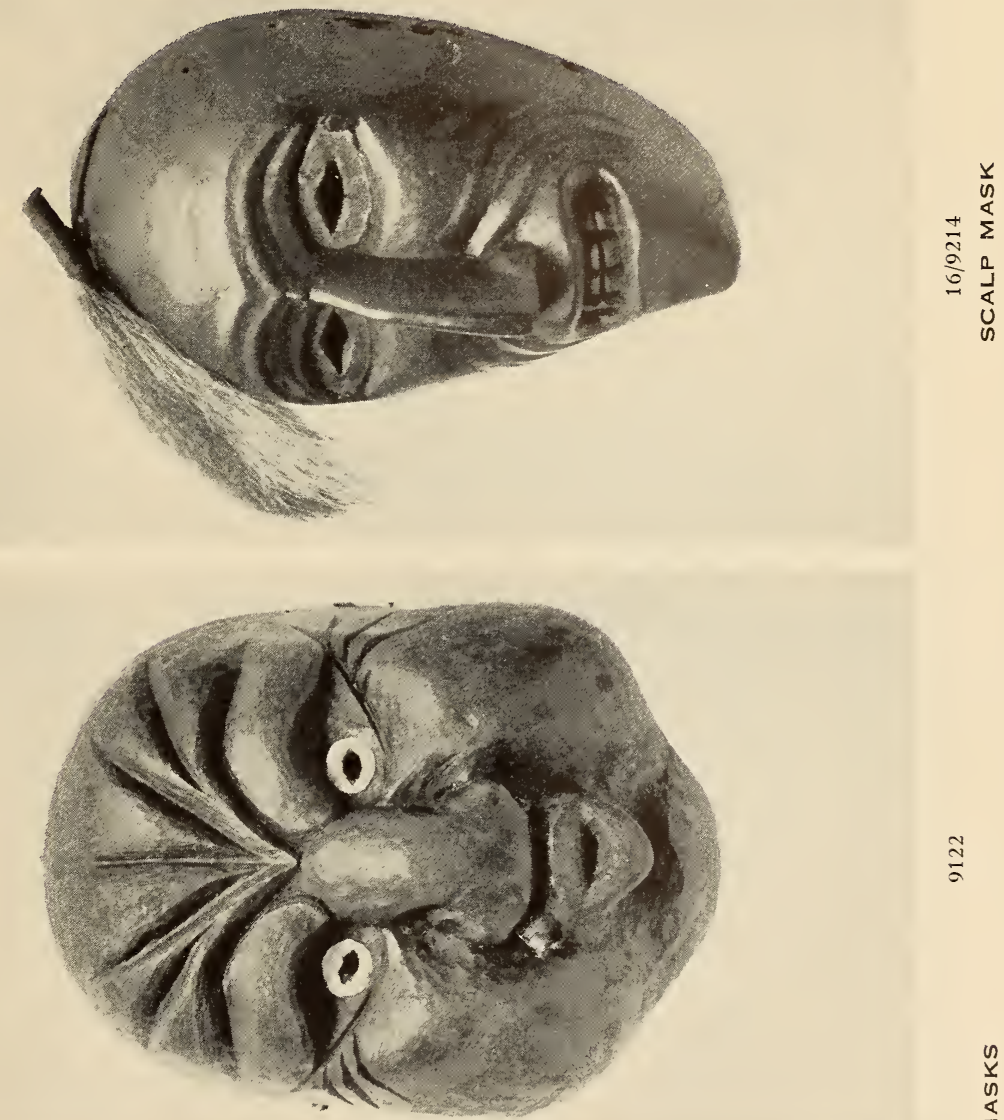

$\frac{\pi}{a}$

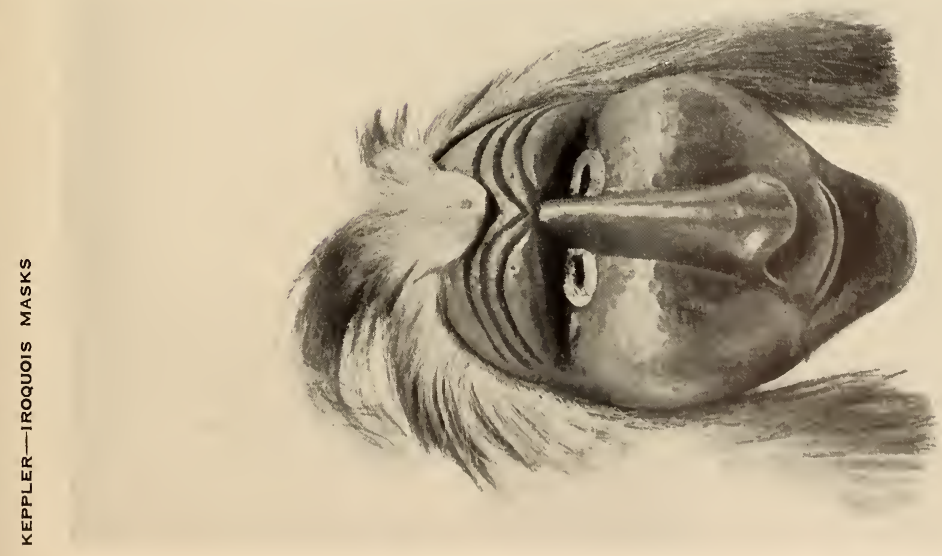

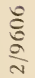


PLATE XI

$6 / 1104$

Монашк, Canada.

Height: $11 \%$ in. Color: Black. 


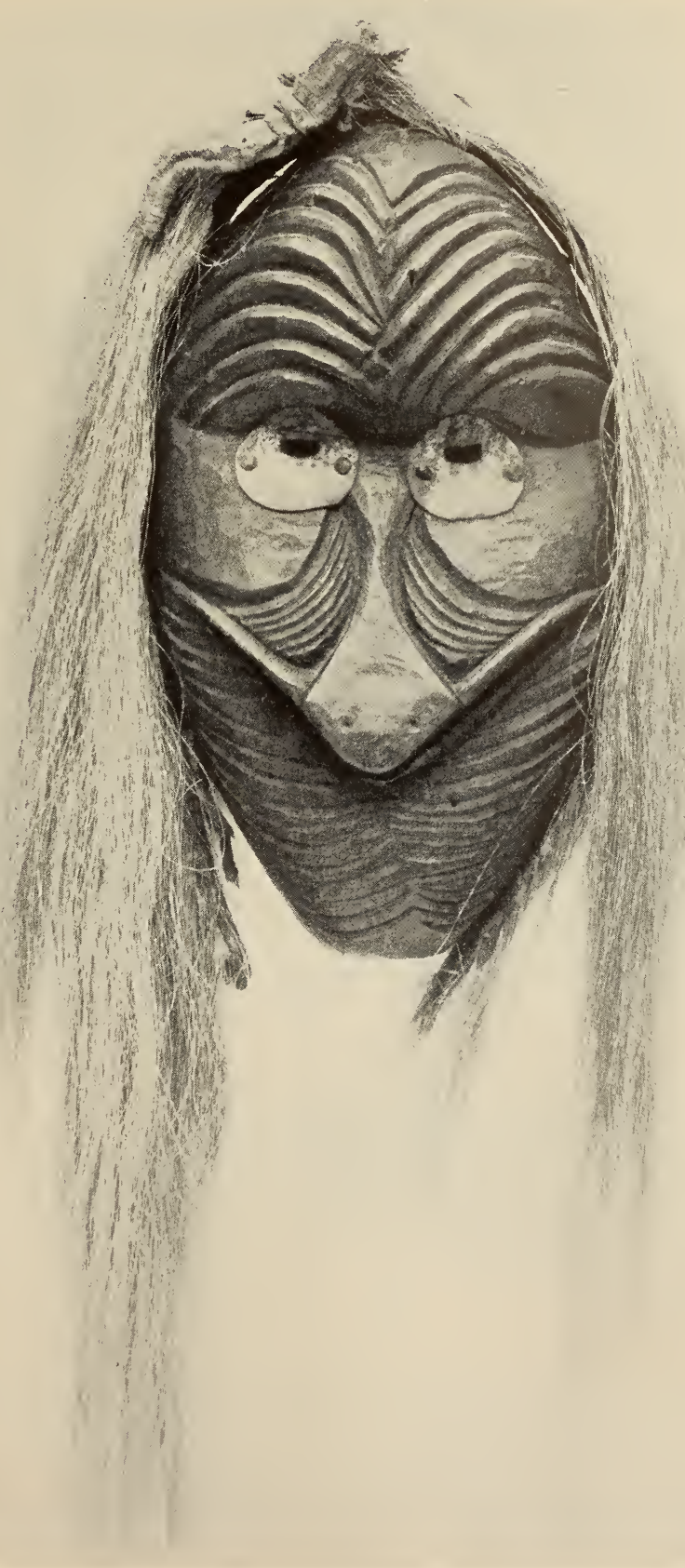

6/1104

CLAN MASK 


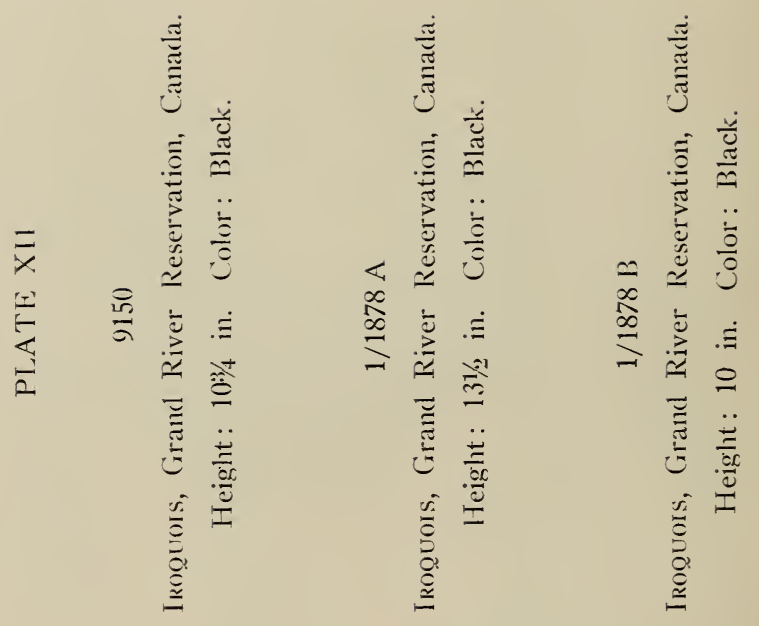



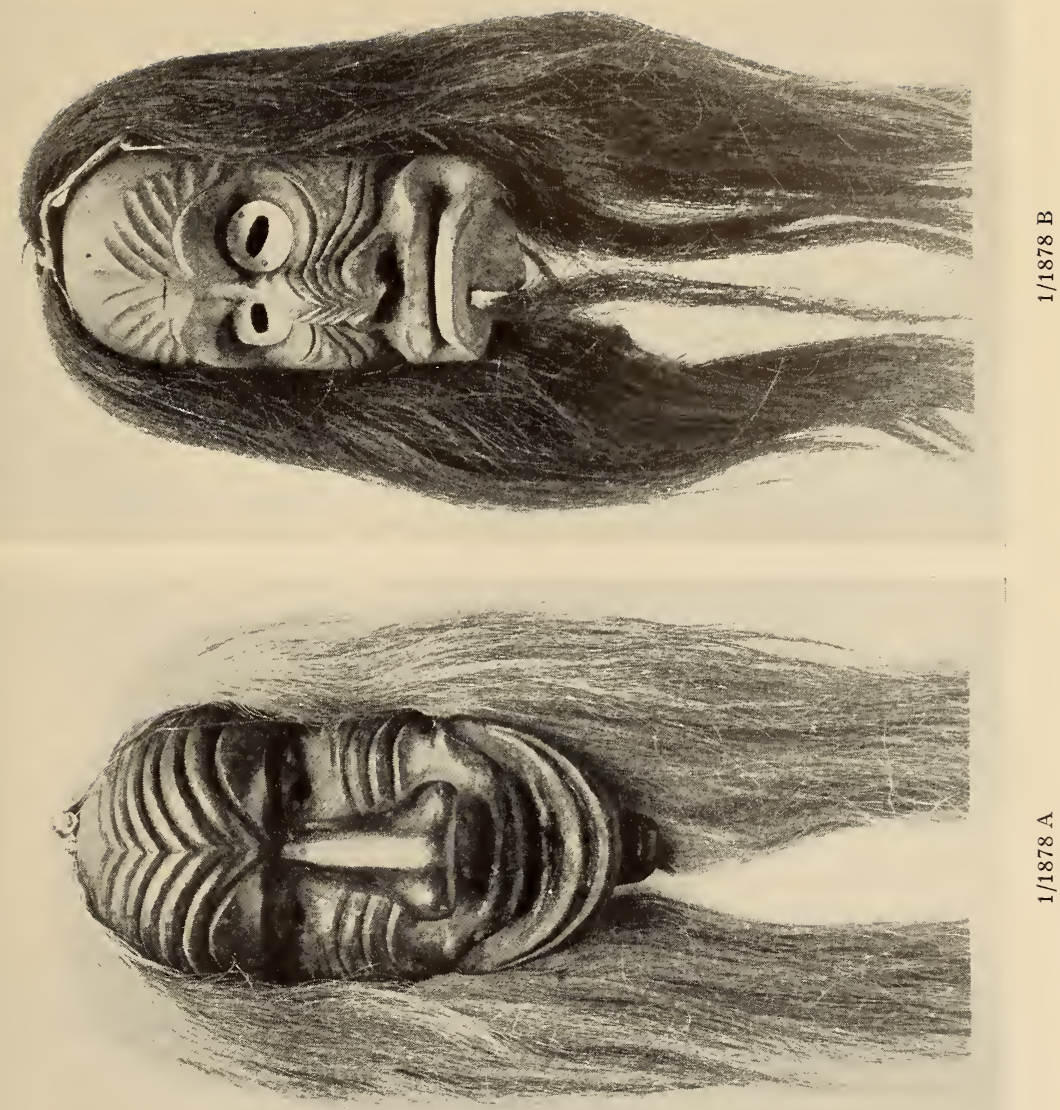

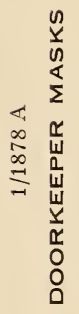
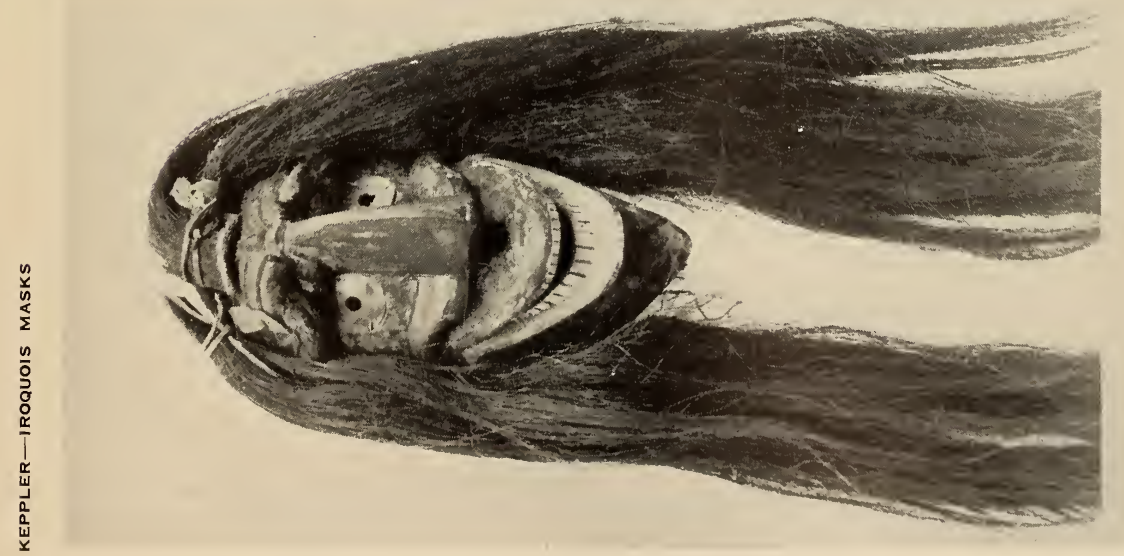
PLATE XIII

6608 Color: Black.

6/337 Color: Red.

6/1109 Color: Gray (stone).

9+20 Color: Natural wood.

Height: $2^{3}, \pm$ in.

2/9809 Color: Red.

All Sexect, Cattaraugus Reserration, New York.

\section{2}

Sexect. Cattaraugus Reservation, New York.

$20 / 2835$

Sexec., Allegany Reservation, New Iork.

\section{$10 / 2853$}

SExECA, Oklahoma. Diam.: 1+1/2 in. 


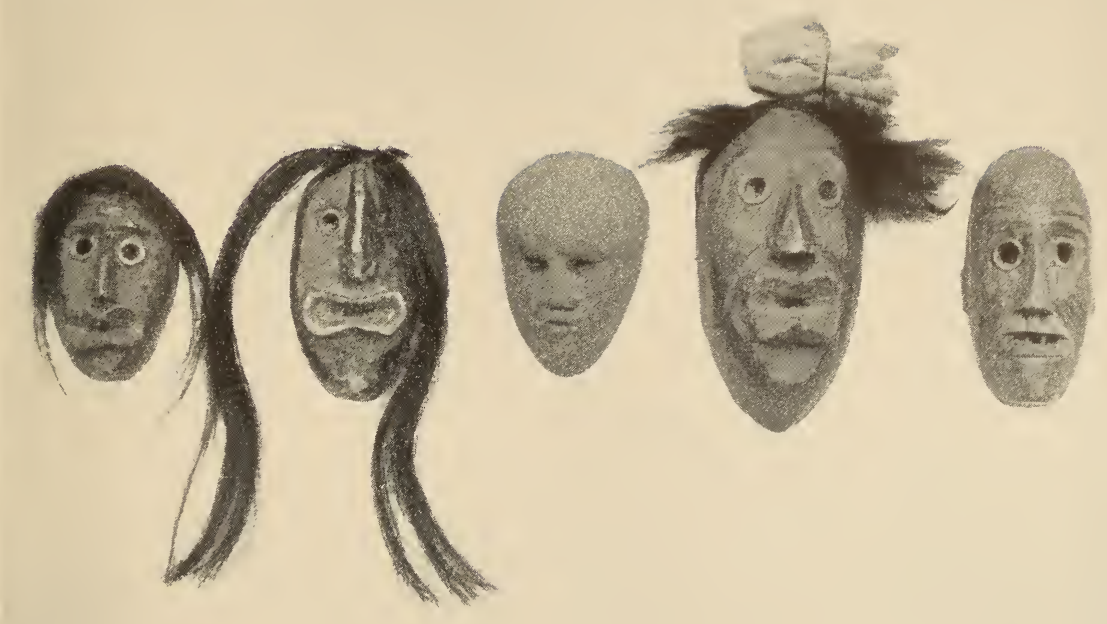

6608

$6 / 337$

$6 / 1109$

9420

2/9809

MINIATURE MASKS

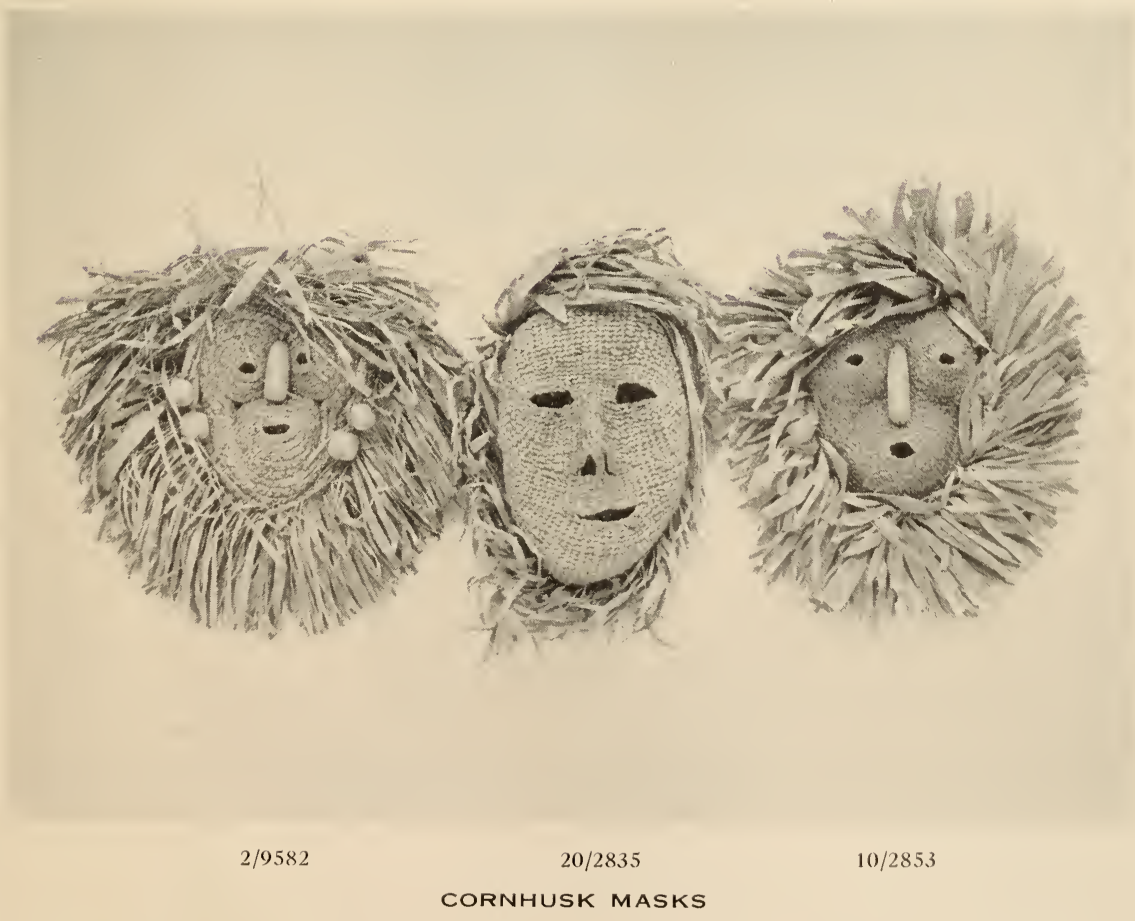



185

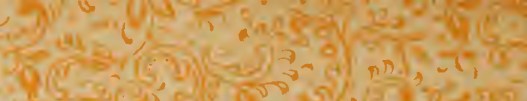
Ln?

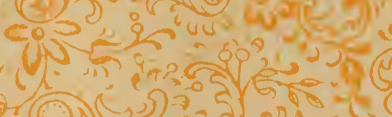

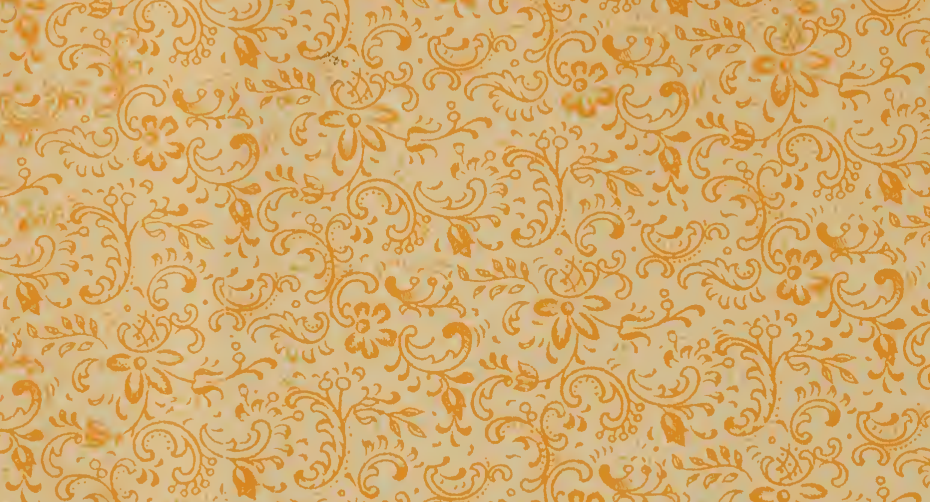

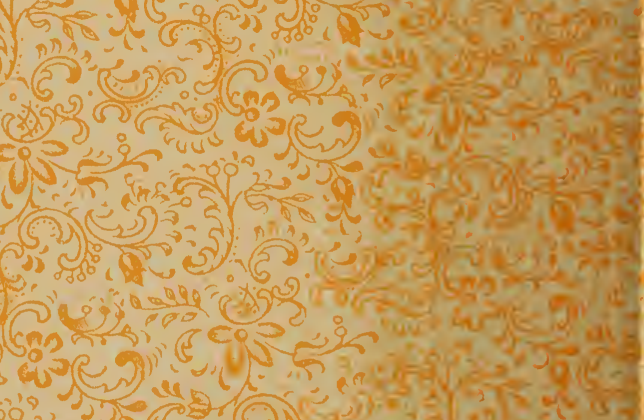

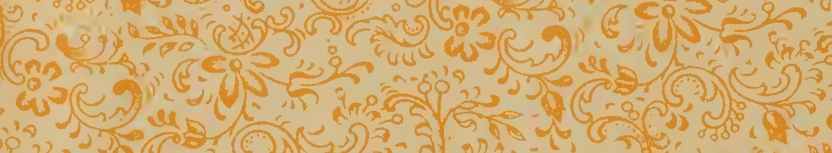

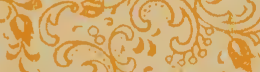

5) $(5,2-25)^{-1}$

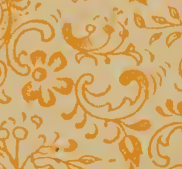

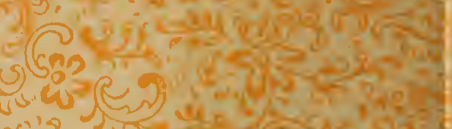

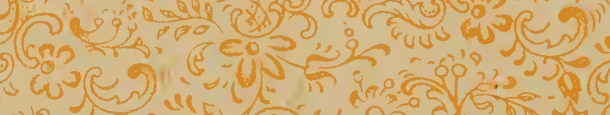

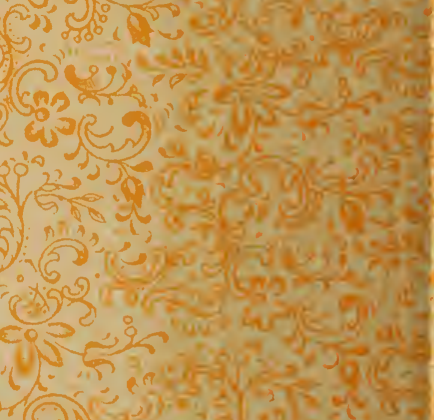
(W. E⿱

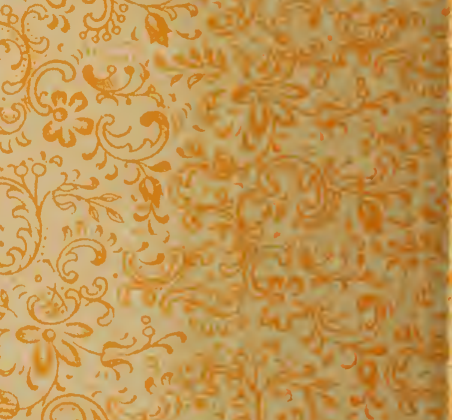

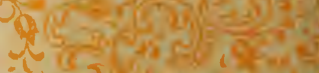

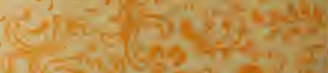

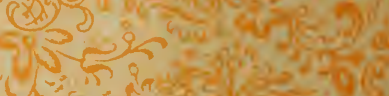

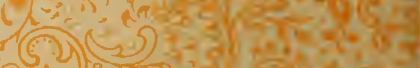
$3(5)$

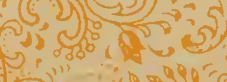

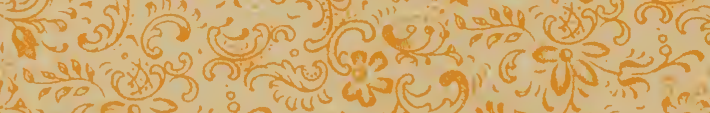

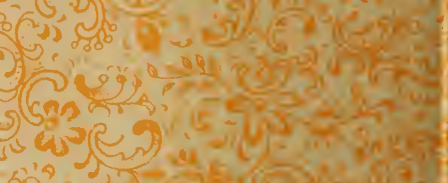

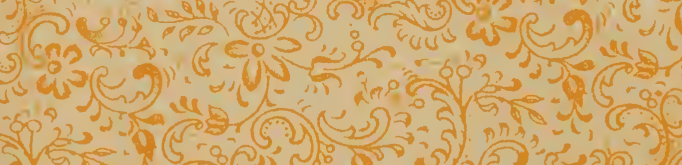

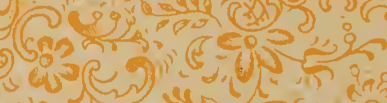

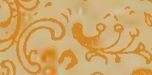
is)

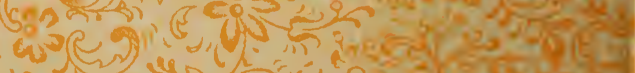

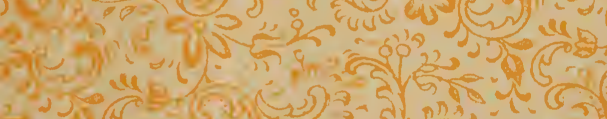
20

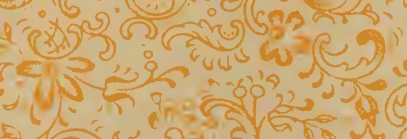

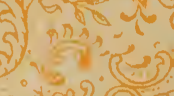

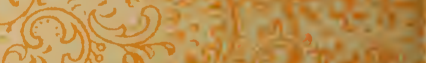

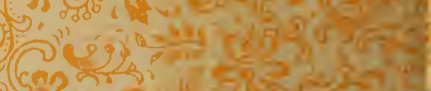

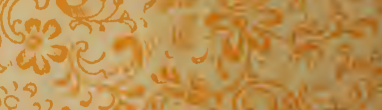

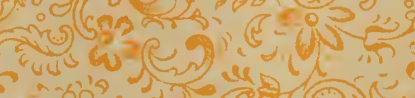

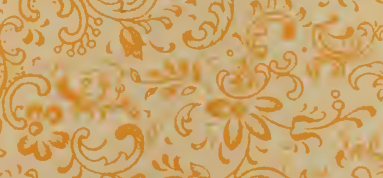

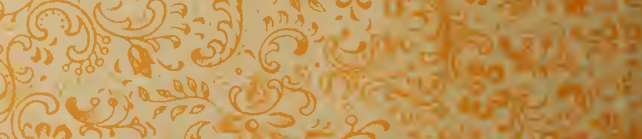
80,8305 


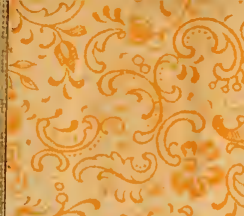

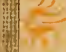

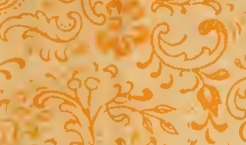

Q⿻一丿火

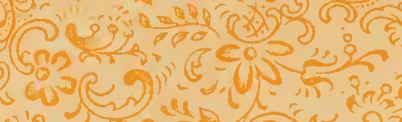

(Cm? a

\section{2}

id

48

$\cos _{0}$

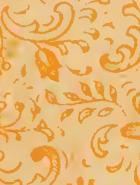

3):

हैं

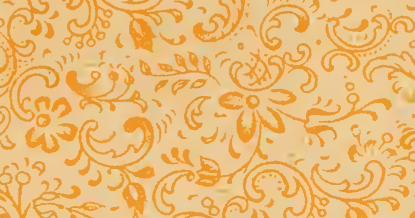

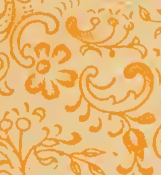

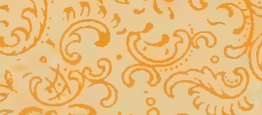

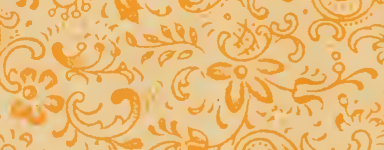

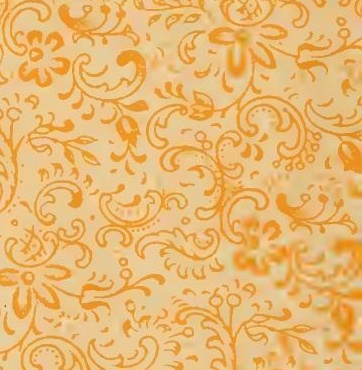

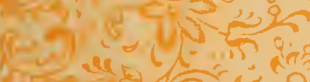

ongerse

cis

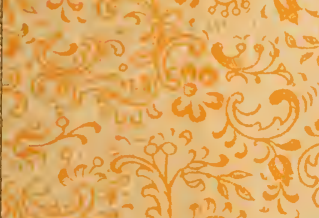

$0 \mathrm{~s} 2$

(2) तु हैं

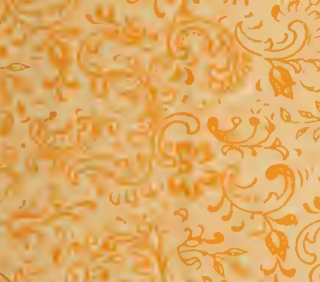

10.

ge in in

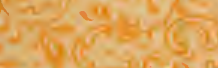

goryoning

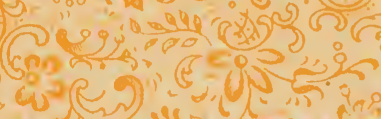

48 .

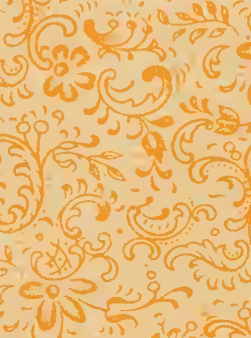

.

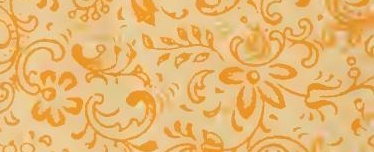

दर्य है ?

(1) - in in

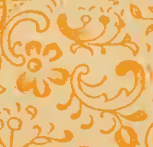

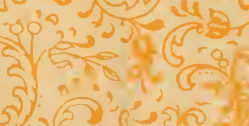

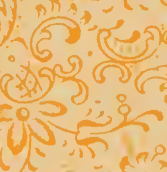

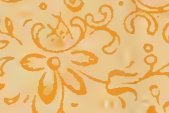

3 son.

3

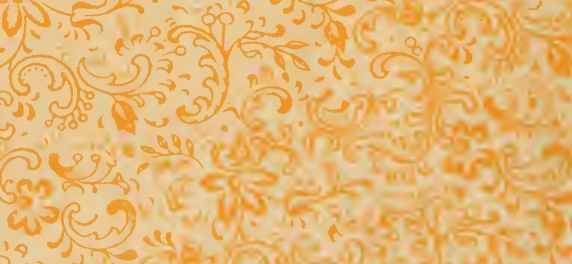

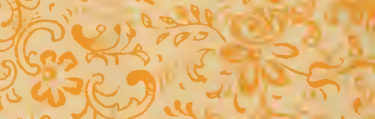

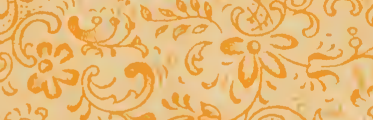

58?

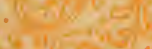

Co

ceste $x^{2}=4$

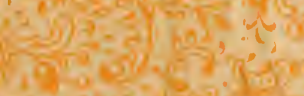

$(3,5)$

$\mathrm{N}(\mathrm{C}$

- 01

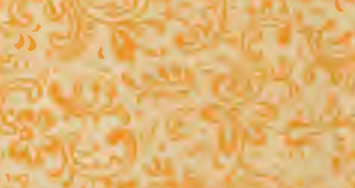

T.

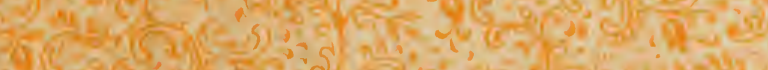

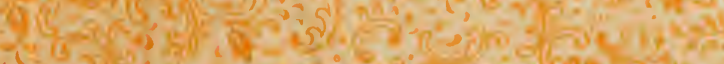

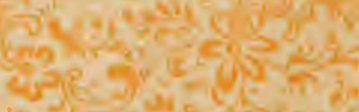

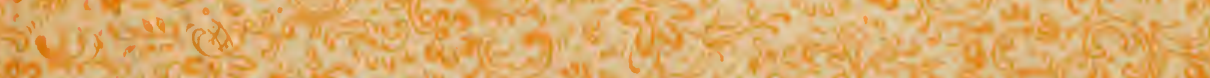
1) 
